\title{
Effects of cutting or grazing grass swards on herbage yield, nitrogen uptake and residual soil nitrate at different levels of $\mathrm{N}$ fertilization
}

\author{
F. Nevens and D. Rehuel \\ Department of Plant Production, Ghent University, Ghent, Belgium
}

\begin{abstract}
On a Flemish sandy loam soil, cut and grazed swards were compared at different levels of mineral nitrogen (N) fertilization. Economically optimal $\mathrm{N}$ fertilization rates were 400 (or more) and $200 \mathrm{~kg} \mathrm{~N} \mathrm{ha}^{-1} \mathrm{yr}^{-1}$ on cut and grazed swards respectively. Considering the amounts of residual soil nitrate- $\mathrm{N}$ in autumn, these $\mathrm{N}$ rates also met the current Flemish legal provisions, i.e. no more than $90 \mathrm{~kg} \mathrm{ha}^{-1}$ nitrate-N present in the 0 $90 \mathrm{~cm}$ soil layer, measured between 1 October and 15 November. The $\mathrm{N}$ use efficiency was considerably higher in cut grassland systems than in grazed systems, even when the animal component of a cut and conservation system was included. The results indicate that, for cut grasslands, two $\mathrm{N}$ application rates should be considered: intensively managed grasslands with high amounts of $\mathrm{N}$ (400 kg ha-1 $\mathrm{yr}^{-1}$ or more) or extensively managed grasslands with white clover and no more than $100 \mathrm{~kg} \mathrm{~N} \mathrm{ha}^{-1} \mathrm{yr}^{-1}$.
\end{abstract}

Keywords: N use efficiency, nitrate leaching, white clover, mowing, grassland management, nitrogen fertilizer

\section{Introduction}

In past decades the yield response of grasslands to nitrogen $(\mathrm{N})$ fertilization has been frequently studied. Due to the difficulty of measuring herbage yield in grazed swards, most of the research was conducted in cutting experiments and there is still a dearth of $\mathrm{N}$-fertilizer rate experiments conducted under grazing (Frame et al., 1998).

Correspondence to: F. Nevens, Department of Plant Production, Ghent University, Coupure Links 653, B-9000 Ghent, Belgium.

E-mail: frank.nevens@rug.ac.be

Received 10 December 2001; revised 22 November 2002
Marginal yield response was used to determine the economically optimal rate of $\mathrm{N}$ application (Behaeghe and Carlier, 1973; Morrison, 1980; Neeteson and Wadman, 1987). The rate of $\mathrm{N}$ application that coincides with this economic yield response optimum might be excessive in terms of the potential for $\mathrm{N}$ losses to the environment (Hopkins, 2000).

More recently, environmental concerns have dominated and much research has focused on the losses of nutrients, in particular $\mathrm{N}$, from intensively managed grassland systems. It is now known that significant amounts of $\mathrm{N}$ may be lost from grasslands by ammonia volatilization (Jarvis et al., 1989; Jarvis, 1990; Scholefield et al., 1991; Bussink, 1992, 1994; Watson et al., 1992), by denitrification (Ryden, 1983; Jordan, 1989; Scholefield et al., 1991; Watson et al., 1992; Vermoesen, 1999) and by nitrate leaching. In view of the European concern for excessive amounts of leached nitrate in groundwater (Anonymous, 1991), numerous studies have been carried out to determine the ecological optimum for grassland $\mathrm{N}$ fertilizer rate. Figure 1 summarizes results from 19 studies dealing with nitrate leaching from grassland soils (Dowdell and Webster, 1980; Dowdell et al., 1980; Garwood et al., 1980; Barraclough et al., 1983; Behaeghe, 1983; Ryden et al., 1984; Jarvis and Cuttle, 1987; Simon et al., 1989; Macduff et al., 1990; Jarvis and Barraclough, 1991; Benke et al., 1992; Garrett et al., 1992; Watson et al., 1992; Scholefield et al., 1993; Decau and Le Corre, 1994; Decau and Salette, 1994; Vertès et al., 1994; Farrugia et al., 1997; Brown et al., 2000). In general, nitrate-leaching losses from grassland increase with increasing $\mathrm{N}$ fertilization, in particular under grazing. In some cases, the losses under grazing are up to five times higher than under cutting. Hack-Ten Broeke (2000) assumed that under Dutch conditions the groundwater nitrate concentration will exceed the EC Nitrates Directive limit of $50 \mathrm{mg} \mathrm{l}^{-1}$ when nitrate- $\mathrm{N}$ leaching exceeds $34 \mathrm{~kg} \mathrm{ha}^{-1} \mathrm{yr}^{-1}$. Figure 1 indicates that, with this assumption, excessive nitrate leaching may be expected when more than approximately $150 \mathrm{~kg}$ of 


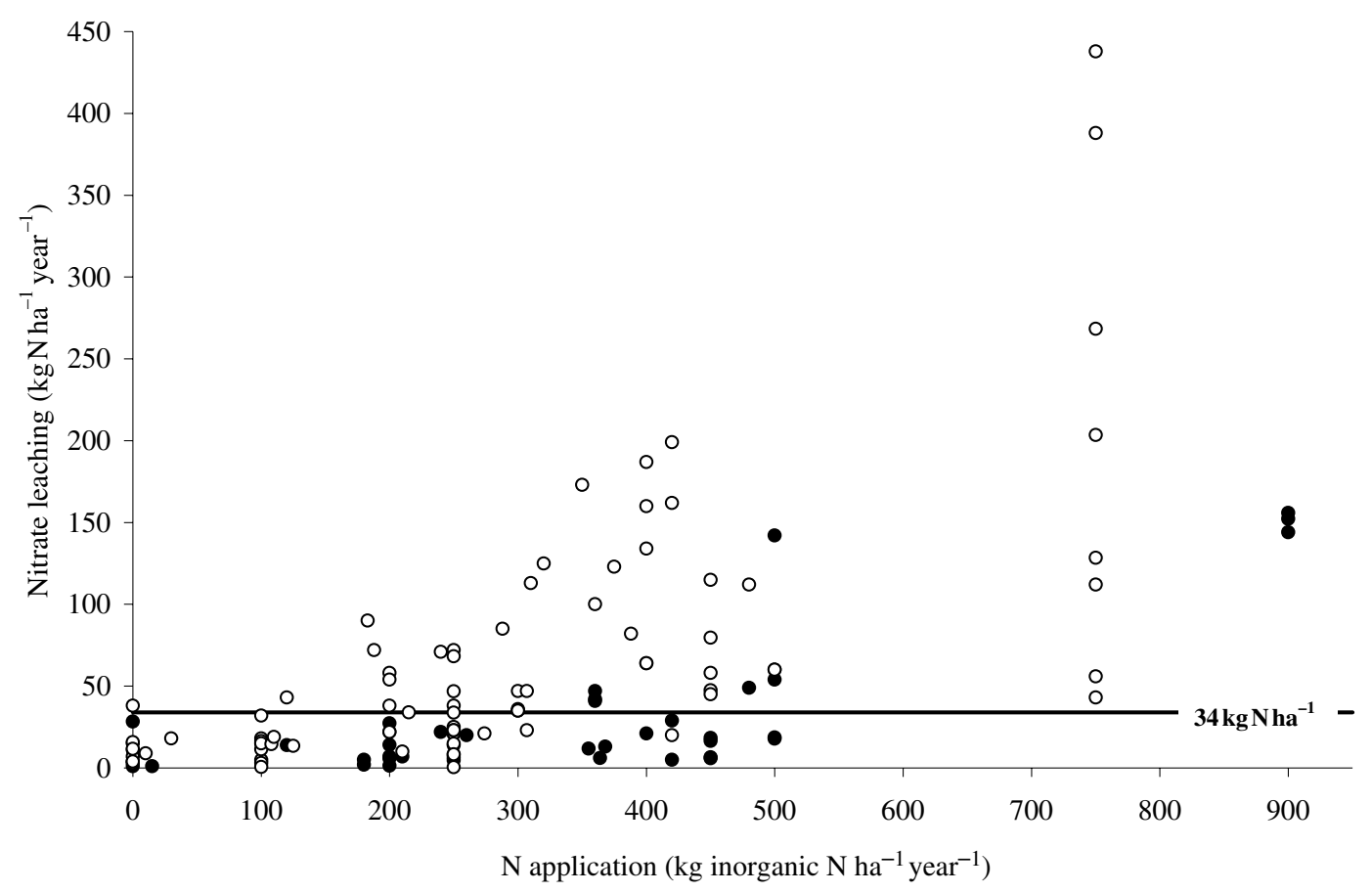

Figure I The amount of nitrogen leached from cut $(\diamond)$ or grazed $(\diamond)$ grasslands (based on nineteen literature references).

$\mathrm{N} \mathrm{ha}^{-1} \mathrm{yr}^{-1}$ is applied under grazing and when more than approximately $450 \mathrm{~kg}$ of $\mathrm{N} \mathrm{ha}^{-1} \mathrm{yr}^{-1}$ is applied under cutting. Willems et al. (2000), using results of Van der Meer and Meeuwissen (1989), drew a comparable conclusion. According to Deenen (1994), the optimal $\mathrm{N}$ application rate should be based on the amount of residual inorganic $\mathrm{N}$ at the end of the growing season rather than on an economic cost benefit analysis.

In Flanders, intensively managed grasslands comprise approximately 270000 ha, an area corresponding to $0 \cdot 41$ of the total agricultural surface (Anonymous, 2001). In view of the current concern for $\mathrm{N}$ losses to ground- and surface-water, the Flemish Government has imposed legislation restricting the use of $\mathrm{N}$ fertilizer on arable land as well as on grassland (the 'Manure Action Plan'; Vlaamse Regering, 2000). Moreover, a limit on residual 'post-harvest' soil nitrate- $\mathrm{N}$ was established: in the period from 1 October to 15 November, no more than $90 \mathrm{~kg}$ of nitrate- $\mathrm{N} \mathrm{ha}^{-1}$ should be present in the soil profile of $0-90 \mathrm{~cm}$. Amounts of residual nitrate exceeding this limit might result in percolation of water with a nitrate concentration higher than $50 \mathrm{mg} \mathrm{l}^{-1}$ (De Clerq et al., 2001). For sandy loam soils, a threshold of $70 \mathrm{~kg}$ of residual soil nitrate- $\mathrm{N} \mathrm{ha}^{-1}$ would actually comply with the European Nitrates Directive for ground- and surface-water (Van Orshoven et al., 2002).
The aim of the experiments described here was to determine and compare the economically optimal $\mathrm{N}$ fertilization rate (the $\mathrm{N}$ rate up to which extra yield pays for extra $\mathrm{N}$ input) and the $\mathrm{N}$ fertilization rate not resulting in excessive residual soil nitrate- $\mathrm{N}$, on cut as well as on grazed grasslands. The research was conducted on a Flemish sandy loam soil, from 1995 to 2000.

\section{Materials and methods}

\section{Cutting experiment}

In 1995, an experiment was conducted on existing grassland (about 30 years old and never reseeded) on a sandy loam soil of the experimental farm of Ghent University at Melle, Belgium $\left(50^{\circ} 59^{\prime} \mathrm{N}, 03^{\circ} 49^{\prime} \mathrm{E}, 11 \mathrm{~m}\right.$ above sea level). The clay $(<2 \mu \mathrm{m})$, silt $(2-50 \mu \mathrm{m})$ and sand $(>50 \mu \mathrm{m})$ contents of the top $27 \mathrm{~cm}$ of soil were 123, 566 and $311 \mathrm{~g} \mathrm{~kg}^{-1}$ respectively. At the start of the experiment (March 1995), the measurement of importance of plant species (determined according to the ranking method of De Vries, 1948) in the sward were $36 \%$ perennial ryegrass (Lolium perenne L.), $43 \%$ rough meadowgrass (Poa trivialis L.), 10\% bent grasses (Agrostis spp.) and $8 \%$ white clover (Trifolium repens L.).

In a four-replicate block design, four levels of inorganic fertilizer were applied: 0, 100, 200 and $400 \mathrm{~kg} \mathrm{~N} \mathrm{ha}^{-1} \mathrm{yr}^{-1}$ (indicated as $0 \mathrm{~N}, 100 \mathrm{~N}, 200 \mathrm{~N}$ 
and $400 \mathrm{~N}$, Table 1). For the $100 \mathrm{~N}$ and $200 \mathrm{~N}$ treatments, the $\mathrm{N}$ application was split into equal rates of $50 \mathrm{~kg} \mathrm{~N} \mathrm{ha}^{-1}$; for the $400 \mathrm{~N}$ treatment, the $\mathrm{N}$ application was split into rates decreasing progressively through the growing season (Table 1). The first $\mathrm{N}$ application was always applied in March; the subsequent $\mathrm{N}$ applications were applied immediately after successive cuts. Phosphorus (P) was applied following local advice for soils with a good P status. Potassium (K) was applied at a rate of $0.83 \mathrm{~kg} \mathrm{~K} \mathrm{~kg}^{-1} \mathrm{~N}$ applied. This is in accordance with the general guideline for cut swards: 0.75-1 kg K kg-1 $\mathrm{N}$ applied (Brown et al., 1969; Brockman, 1971; Robson et al., 1989). On the $0 \mathrm{~N}$ plots, the $\mathrm{K}$ rate was rather high $\left(166 \mathrm{~kg} \mathrm{ha}^{-1} \mathrm{yr}^{-1}\right)$ to allow white clover to develop successfully. The plots were cut on a production-based schedule, aiming at yields of 3000$4000 \mathrm{~kg}$ dry matter (DM) ha ${ }^{-1}$ cut $^{-1}$. The grass was mowed with an engine-driven cutter bar mower; the cutting height was approximately $5 \mathrm{~cm}$. Each individual experimental plot measured $58 \mathrm{~m}^{2}$; the experimental area was $25 \cdot 8 \mathrm{~m}^{2}$. Nitrogen concentration (Kjeldahlmethod), organic matter digestibility (OMD, Near Infrared Reflectance Spectroscopy) and crude ash concentration of the herbage of each cut were determined. The analyses were carried out in duplicate on herbage samples bulked per cut and per treatment.

The energy value of the herbage was determined following the method of the Centraal Veevoeder Bureau (C.V.B., 1992). According to this Dutch system, the energy value of forages is expressed as net energy for lactation (NEL, $\left.\mathrm{kJ} \mathrm{kg}^{-1} \mathrm{DM}\right)$ and calculated as follows:

where

$$
\mathrm{NEL}=0 \cdot 6[1+0 \cdot 004(\mathrm{q}-57)] 0 \cdot 9752 \mathrm{ME},
$$

$$
M E= \begin{cases}14.2 \mathrm{DOM}+5.9 \mathrm{DCP} & \text { if DOM } / \mathrm{DCP}<7 \\ 15.5 \mathrm{DOM} & \text { if DOM } / \mathrm{DCP}>7,\end{cases}
$$

and $\mathrm{q}=100 \times \mathrm{ME} / \mathrm{GE}$.

$\mathrm{DOM}=\mathrm{OMD}(1000-\mathrm{ash}) / 100$ and DOM $=$ digestible organic matter $\left(\mathrm{g} \mathrm{kg}^{-1} \mathrm{DM}\right), \mathrm{OMD}$ (organic matter digestibility, \%), ash $\left(\mathrm{g} \mathrm{kg}^{-1} \mathrm{DM}\right)$ and $\mathrm{DCP}=0.959$
$\mathrm{CP}+0.04$ ash-40. $\mathrm{DCP}=$ digestible crude protein $\left(\mathrm{g} \mathrm{kg}^{-1} \mathrm{DM}\right)$ and $\mathrm{CP}=\mathrm{N}$-content $\times 6 \cdot 25 . \mathrm{ME}=$ metabmetabolizable energy $\left(\mathrm{kJ} \mathrm{kg}^{-1} \mathrm{DM}\right)$ and $\mathrm{GE}=$ gross energy $\left(\mathrm{kJ} \mathrm{kg}^{-1} \mathrm{DM}\right)$. GE $=18000 \mathrm{~kJ} \mathrm{~kg}^{-1} \mathrm{DM}$ (Andrieu et al., 1988; Flachowsky, 1993).

Multiplying the DM yield of each cut by the corresponding energy value and adding up for all the cuts resulted in the annual energy yields for each of the fertilization treatments.

To express and evaluate the efficiency of applied fertilizer $\mathrm{N}$, the apparent $\mathrm{N}$ effect (Deenen, 1994) or herbage yield response to applied fertilizer $\mathrm{N}$ was calculated as:

$$
\begin{array}{r}
\text { Yield response }\left(X_{1} \rightarrow X_{2}\right)=\frac{\text { Yield }\left(X_{2}\right)-\text { Yield }\left(X_{1}\right)}{X_{2}-X_{1}} \\
\left(\mathrm{~kg} \mathrm{DM} \mathrm{kg}^{-1} \mathrm{~N} \text { or GJ NEL kg }{ }^{-1} \mathrm{~N}\right),
\end{array}
$$

$\mathrm{X} 1, \mathrm{X} 2=$ inorganic fertilizer rate $\left(\mathrm{kg} \mathrm{N} \mathrm{ha}^{-1} \mathrm{yr}^{-1}\right)$.

At the end of the growing seasons (12 November 1996, 12 November 1997, 26 October 1998 and 8 November 1999), the amount of residual soil nitrate-N was measured. On each individual plot, four random areas were sampled using gauge augers. Three soil depths were sampled: A $(0-30 \mathrm{~cm}), \mathrm{B}(30-60 \mathrm{~cm})$ and C (60-90 cm). For each treatment and each soil depth, the twelve soil cores ( 3 plots $\times 4$ cores per plot) were bulked, two sub-samples of $30 \mathrm{~g}$ were extracted with a $1 \% \mathrm{KAl}(\mathrm{SO} 4)_{2}$-solution and the nitrate concentration was measured in duplicate with a nitrate-specific electrode (Cottenie and Velghe, 1973; Hofman, 1983).

On 31 March 1998 and 18 September 2000, within each individual plot in forty quadrats of $10 \mathrm{~cm} \times 10 \mathrm{~cm}$, white clover presence was determined (Kent and Coker, 1992). Measurement of frequency is a good alternative for density measurements when clonal species (e.g. white clover) are present (Whalley and Hardy, 2000). On 27 March 1998, a botanical analysis according to the method of De Vries $(1933,1948)$ was also carried out. This method is a dry-weight ranking method, which is the simplest procedure for estimating
Table I Amounts of nitrogen $(\mathrm{N})$, phosphorus ( $P$ ) and potassium (K) fertilizer $\left(\mathrm{kg} \mathrm{ha}^{-1}\right)$ applied to the experimental treatments in the cutting and grazing experiments.

\begin{tabular}{lllc}
\hline Treatment & N (split applications) & P & K (split applications) \\
\hline Cutting experiment & 0 & 35 & $166(83-83)$ \\
$0 \mathrm{~N}$ & $100(50-50)$ & 35 & $83(42-42)$ \\
$100 \mathrm{~N}$ & $200(50-50-50-50)$ & 35 & $166(83-83)$ \\
$200 \mathrm{~N}$ & $400(100-90-80-70-60)$ & 35 & $332(116-108-108)$ \\
$400 \mathrm{~N}$ & 0 & & \\
Grazing experiment & 26 & $42(25-17)$ \\
$0 \mathrm{~N}$ & $200(50-50-50-50)$ & 26 & $42(25-17)$ \\
$200 \mathrm{~N}$ & $400(80-80-80-80-80)$ & 26 & $42(25-17)$ \\
$400 \mathrm{~N}$ &
\end{tabular}

$\mathrm{N}$, calcium ammonium nitrate $(27 \%)$; $\mathrm{P}$, triple superphosphate $(43 \%)$; $\mathrm{K}$, muriate of potash $(40 \%)$. 
the proportion by dry weight of the different species in grassland (Whalley and Hardy, 2000). On each plot, forty samples (forty cores corresponding with an area of $28.3 \mathrm{~cm}^{2}$ each) were analysed after ten growing days in a greenhouse.

\section{Grazing experiment}

A grazing experiment was conducted in the spring of 1996 at the same site. Three $\mathrm{N}$ fertilizer treatments were carried out in a $3 \times 3$ Latin square: 0,200 or $400 \mathrm{~kg}$ inorganic $\mathrm{N} \mathrm{ha}^{-1} \mathrm{yr}^{-1}$ (Table 1). Phosphorus was applied at $26 \mathrm{~kg} \mathrm{ha}^{-1}$, following local advice for soils with a good P status. As grazing heifers return a large amount of nutrients in faeces and in urine, the net $\mathrm{K}$ uptake is very low. According to Williams (1980) and Van de Ven (1990), 15-42 $\mathrm{kg} \mathrm{K} \mathrm{ha}^{-1} \mathrm{yr}^{-1}$ should be adequate to meet the needs of a grazed sward. In this experiment, $\mathrm{K}$ was applied at $42 \mathrm{~kg} \mathrm{ha}^{-1}$.

Heifers (average age and live weight at the start of the growing season: 14 months and $354 \mathrm{~kg}$ respectively) rotationally grazed the nine paddocks, each measuring $975 \mathrm{~m}^{2}$. The heifers were moved to the next plot when the herbage was grazed down to a height of approximately $7 \mathrm{~cm}$. Buffer strips with a total area of $3000 \mathrm{~m}^{2}$ were available for grazing during periods of shortage on the experimental plots. The grazing seasons of 1996, 1997, 1998 and 1999 started on 29, 18, 21 and 28 April, respectively, and lasted 178, 161, 178 and $176 \mathrm{~d}$ respectively.

Plot-to-plot nutrient carry-over by the excreta of the heifers would have occurred. Nevertheless, nutrient translocations by animals moving to a next paddock was always compensated by nutrient input by the animals entering again from another paddock during the next grazing round. As the plot grazing sequence was altered for each grazing round, these compensations were randomized in the long term.

Total grass yields were calculated by measuring heifer performance during grazing (Woolfolk, 1962; Lantinga et al., 1987; Coates and Penning, 2000). According to Bransby and Maclaurin (2000), total heifer production $\mathrm{ha}^{-1}$ can be calculated as $\mathrm{PH} \times \mathrm{SR} \times \mathrm{T}$, where $\mathrm{PH}$ is the daily production per heifer $(\mathrm{kg}), \mathrm{SR}$ is the stocking rate (heifers $\mathrm{ha}^{-1}$ ) and $T$ is the grazing time in days.

SR and $T$ were derived from recording the number of heifers (five to eight, depending on the availability of grass during the grazing season) and the duration of the subsequent grazing periods on each of the individual experimental plots. To determine $\mathrm{PH}$, the live weightbased daily energy demands of growing and grazing heifers currently used in the Netherlands (I.K.C., 1993) were applied. These demands are expressed as Dutch Feed Units [VEM = 'Voedereenheid Melk (Dutch Feed Unit milk)] (Table 2). The VEM values were transformed into $\mathrm{GJ} \mathrm{ha}^{-1}$, assuming that 1 VEM corresponds to 6.9 kJ NEL (Van Es, 1978; Deenen and Lantinga, 1993). At the start of the grazing season, the heifers were weighed after an adaptation period of about $8 \mathrm{~d}$ of grazing on the buffer plots. During the grazing season, the animals were weighed at intervals of 1 month and finally when they returned to the cowshed in October.

There is a possible inherent lack of precision in the estimation of absolute grassland productivity as it was based on theoretical energy demands and not on direct measurements. Nevertheless, the method used has proved to be useful for obtaining relative measures of herbage intake in pastures (Baker, 1982; Deenen and Lantinga, 1993) and this was the major objective of this research, i.e. comparing productivity of swards at different $\mathrm{N}$ application rates. In addition, other methods show drawbacks, e.g. measuring grazed grassland yields by herbage accumulation under exclosure cages tends to overestimate herbage intake (Deenen and Lantinga, 1993).

Moreover, the method used incorporates grazing time as a response variable as grazing was ended on different treatments or plots at different times, based on an objective criterion - canopy height. According to Bransby and Maclaurin (2000), this time factor is often completely overlooked in experiments measuring animal production.

The $\mathrm{N}$ yield in liveweight gain was calculated for each fertilizer treatment by multiplying observed liveweight gains by an average $\mathrm{N}$ concentration of $25 \mathrm{~g} \mathrm{~kg}^{-1}$ (Carlier et al., 1992; Anonymous, 2000a).

In the same way as in the cutting experiment, at the end of the growing season soil samples were taken to determine the amount of residual nitrate-N. However, on these larger and grazed plots (on which a larger variability was expected), the number of cores was increased to ten in each plot and a bulked sample of each individual plot was analysed in duplicate. The methods of analysis were the same as in the cutting experiment.

On 27 March 1998 in forty quadrats of $10 \mathrm{~cm} \times 10 \mathrm{~cm}$ in each plot, the presence of white clover was determined (as in the cutting experiment). On the same date, a botanical analysis, according to the

Table 2 Net energy (NE) demand (MJ NEL day ${ }^{-1}$ ) of growing dairy heifers as a function of their live weight $(\mathrm{kg})$.

\begin{tabular}{llllllllll}
\hline Live weight & $\mathbf{1 7 5}$ & $\mathbf{2 2 5}$ & $\mathbf{2 6 5}$ & $\mathbf{3 0 5}$ & $\mathbf{3 5 0}$ & $\mathbf{3 8 5}$ & $\mathbf{4 2 5}$ & $\mathbf{4 6 0}$ & $\mathbf{5 0 0}$ \\
\hline NE demand & $29 \cdot 0$ & $35 \cdot 2$ & $35 \cdot 9$ & $39 \cdot 7$ & $44 \cdot 2$ & $46 \cdot 2$ & $50 \cdot 0$ & $54 \cdot 9$ & $61 \cdot 4$ \\
\hline
\end{tabular}


method of De Vries (1933, 1948), was also carried out. On each plot, forty core samples each of $28.3 \mathrm{~cm}^{2}$ were analysed.

On-site weather data for the growing seasons are shown in Figures 2 and 3.

\section{Statistical analyses}

Analyses of variance were performed using the STATITCF software package of INRA (Institut National de la Recherche Agronomique, France). Homogenous groups were determined using the test of NewmanKeuls.

\section{Results and discussion}

\section{Cutting experiment}

\section{Botanical composition}

Significant botanical shifts occurred in the grassland (Table 3). The presence of white clover increased strongly in the $0 \mathrm{~N}$ and the $100 \mathrm{~N}$ swards and its frequency and importance percentage were significantly higher $(P<0.001)$ than in the $200 \mathrm{~N}$ and the $400 \mathrm{~N}$ plots. The white clover content increased at the expense of L. perenne: compared with an initial value of
$36 \%$, the percentage of perennial ryegrass on the $0 \mathrm{~N}$ and $100 \mathrm{~N}$ plots decreased to $15 \%$ and $19 \%$ respectively. On the $200 \mathrm{~N}$ and $400 \mathrm{~N}$ plots, the presence of $L$. perenne increased to $39 \%$ and $49 \%$, respectively, when measured in March 1998.

\section{Dry-matter yield}

The DM yields from 1995 to 2000 are summarized in Figure 4. When compared with references in the literature (Hopkins, 2000), the yields of the $400 \mathrm{~N}$ treatment (on average $16.6 \mathrm{Mg} \mathrm{DM} \mathrm{ha}^{-1} \mathrm{yr}^{-1}$ ) illustrate a very high production on the site. On the $100 \mathrm{~N}$ and $200 \mathrm{~N}$ plots high average yields were obtained 13.8 and $14.7 \mathrm{Mg} \mathrm{DM} \mathrm{ha}^{-1} \mathrm{yr}^{-1}$ respectively. The DM yields reflected the growing conditions and management in an experiment which are better, on average, than on a farm. Moreover, under practical conditions, harvesting, conservation and feeding losses occur, resulting in lower net yields. These losses will not be considered in the discussion on optimal rate of $\mathrm{N}$ as they only change the height of the response curves, not the slopes.

The variability of DM yield and $\mathrm{N}$ response among years was quite high (Hopkins, 2000). Elgersma et al. (1998) found high yield variability owing to the white clover content changing between years.

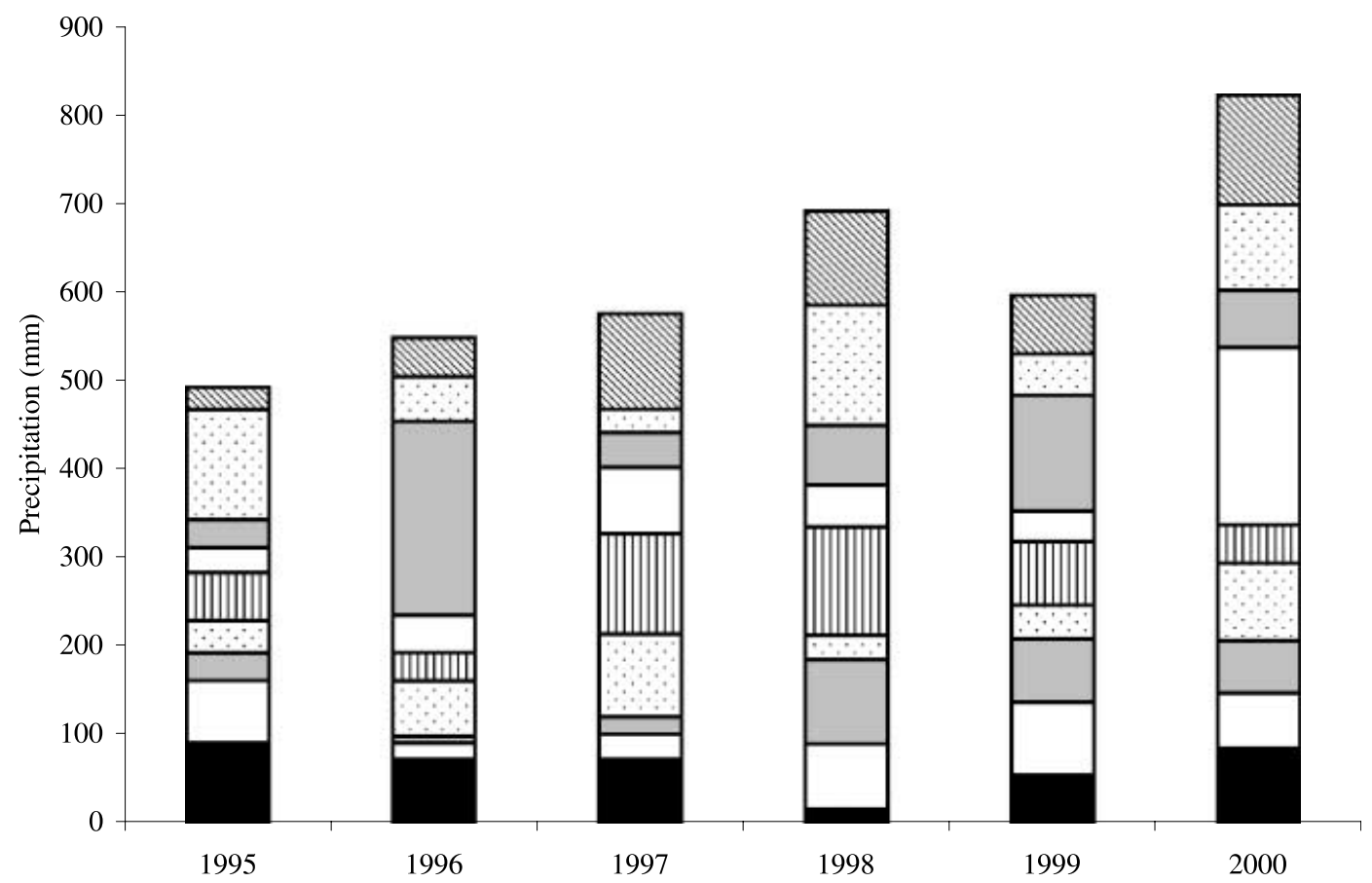

Figure 2 Precipitation during the growing season at Melle, 1995-2000: (\$ October; $\$$ September; $\square$ August; $\square$ July; 四 June; $\square$ May; $\square$ April; $\square$ March; $\square$ February). 


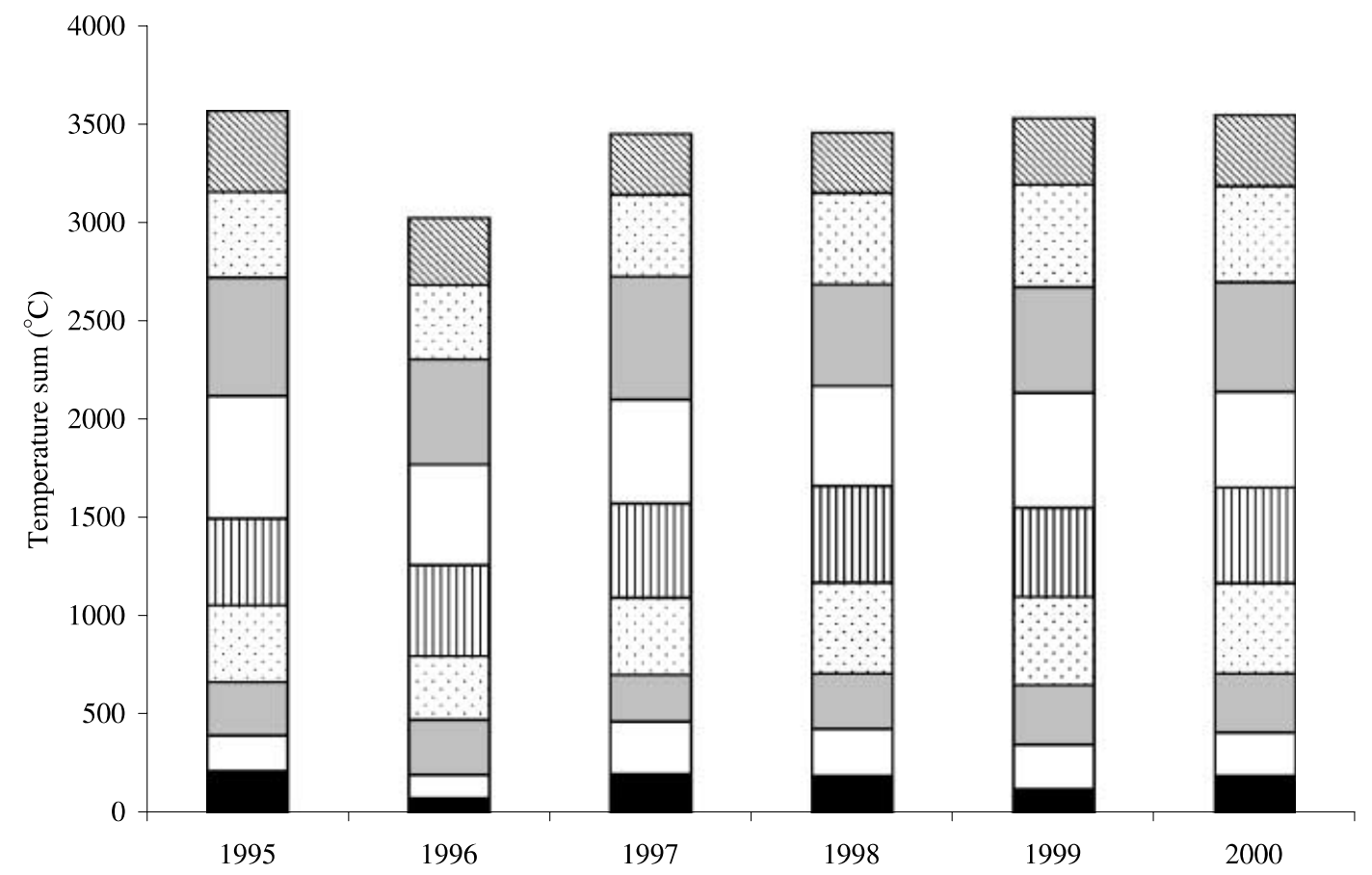

Figure 3 Temperature sum (addition of the positive average daily temperatures) during the growing season at Melle, 1995-2000:

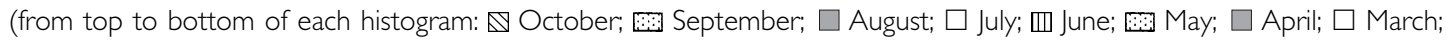

- February).

\begin{tabular}{|c|c|c|c|c|c|}
\hline \multirow[b]{2}{*}{ Species } & \multicolumn{4}{|c|}{$\mathrm{N}$ rate $\left(\mathrm{kg} \mathrm{ha}^{-1} \mathrm{yr}^{-1}\right)$} & \multirow{2}{*}{$\begin{array}{c}\text { Significance } \\
\text { of } \mathbf{N} \text { rate }\end{array}$} \\
\hline & $\mathbf{0}$ & 100 & 200 & 400 & \\
\hline \multicolumn{6}{|c|}{ Importance percentage on 15 March 1995} \\
\hline Lolium perenne L. & \multicolumn{4}{|c|}{$35 \cdot 9$} & \\
\hline Poa trivialis $\mathrm{L}$. & \multicolumn{4}{|c|}{$43 \cdot 4$} & \\
\hline Agrostis spp. & \multicolumn{4}{|c|}{$9 \cdot 6$} & \\
\hline Trifolium repens $\mathrm{L}$. & \multicolumn{4}{|c|}{$7 \cdot 6$} & \\
\hline \multicolumn{6}{|c|}{ Importance percentage on 31 March 1998} \\
\hline Lolium perenne $\mathrm{L}$. & $15 \cdot 0^{\mathrm{c}}$ & $18 \cdot 5^{\mathrm{c}}$ & $39 \cdot 4^{\mathrm{b}}$ & $49 \cdot 1^{\mathrm{a}}$ & $* * *$ \\
\hline Poa trivialis $\mathrm{L}$. & $37 \cdot 8^{\mathrm{a}}$ & $36 \cdot 9^{\mathrm{a}}$ & $41 \cdot 3^{\mathrm{a}}$ & $36 \cdot 7^{\mathrm{a}}$ & NS \\
\hline Agrostis spp. & $7 \cdot 1^{\mathrm{a}}$ & $6 \cdot 6^{\mathrm{a}}$ & $6 \cdot 4^{\mathrm{a}}$ & $8 \cdot 7^{\mathrm{a}}$ & NS \\
\hline Trifolium repens $\mathrm{L}$. & $32 \cdot 9^{\mathrm{a}}$ & $28 \cdot 4^{\mathrm{a}}$ & $9 \cdot 2^{\mathrm{b}}$ & $2 \cdot 6^{\mathrm{b}}$ & $* * *$ \\
\hline \multicolumn{6}{|c|}{ Frequency (\%) of Trifolium repens $\mathrm{L}$. } \\
\hline 31 March 1998 & $97 \cdot 0^{\mathrm{a}}$ & $86 \cdot 0^{\mathrm{a}}$ & $50 \cdot 0^{\mathrm{b}}$ & $12 \cdot 0^{\mathrm{c}}$ & $* * *$ \\
\hline 18 September 2000 & $93 \cdot 8^{a}$ & $90 \cdot 6^{\mathrm{a}}$ & $62 \cdot 5^{\mathrm{b}}$ & $13 \cdot 8^{\mathrm{c}}$ & $* * *$ \\
\hline
\end{tabular}

Table 3 Importance percentage of plant species and frequency of Trifolium repens in the swards to which $\mathrm{N}$ fertilizer treatments were applied in the cutting experiment.

Within one row, values with different letters are significantly different at $P<0.05$

(Newman-Keuls test).

$* * * P<0.001 ;$ NS, non-significant.

Relative to the 6-year mean of DM yield at $400 \mathrm{~N}$, the DM yield was $0.88,0 \cdot 83$ and 0.69 of the $200 \mathrm{~N}, 100 \mathrm{~N}$ and $0 \mathrm{~N}$ treatments respectively. As a result of the increasing amount of white clover in the $0 \mathrm{~N}$ sward, a remarkably high yield was obtained on these plots from 1997 onwards. Another factor allowing relatively high yields under zero or low $\mathrm{N}$-fertilization was the yieldbased cutting regime. Compared with a much easier to perform time-based regime, the cutting system used allowed longer growing periods and hence higher yields on the less fertilized plots (Holliday and Wilman, 1965). According to Wilman and Asiegbu (1982) and 


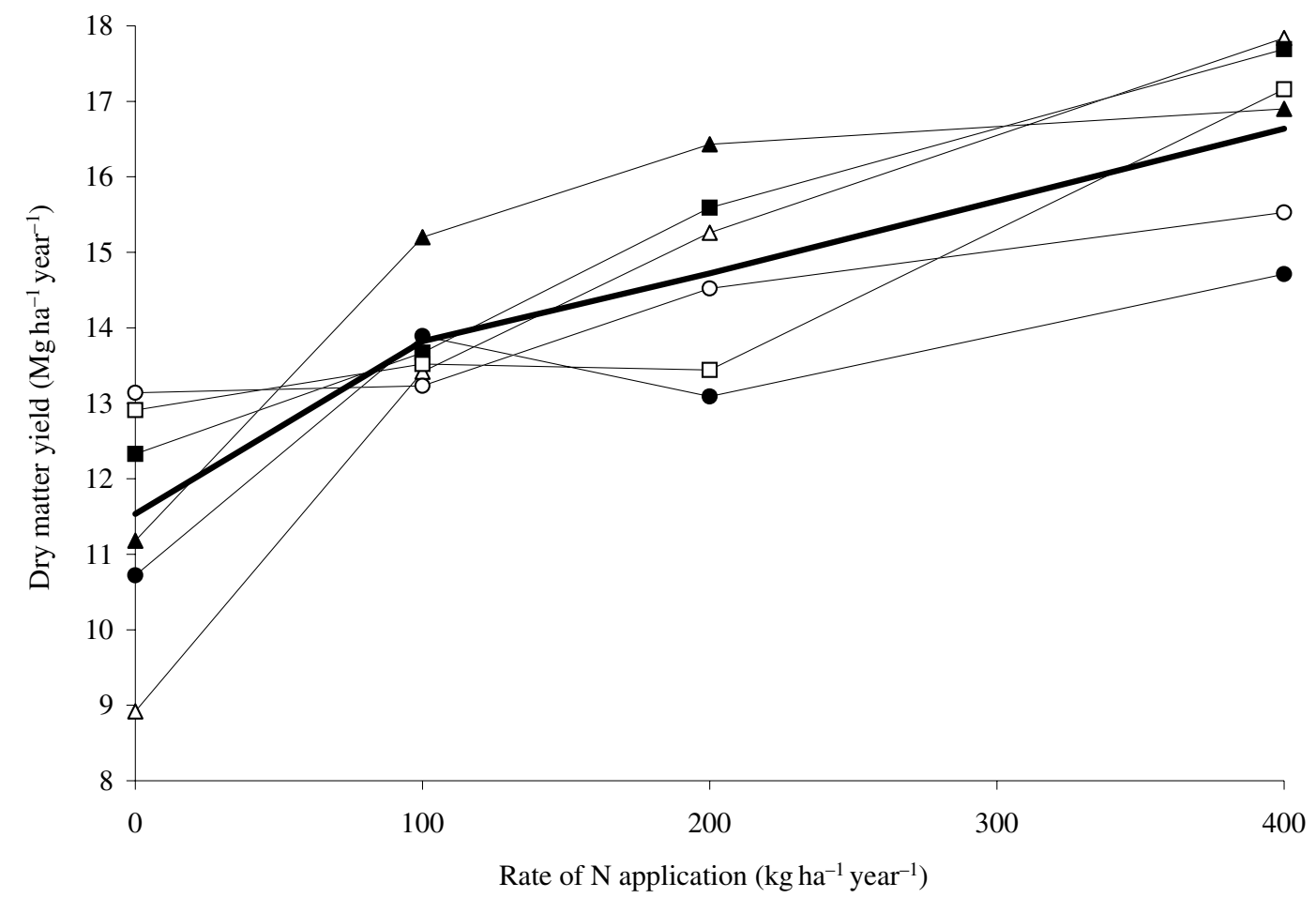

Figure 4 Dry-matter yields in the cutting experiment in 1995 $(\mathbf{\Delta}), 1996(\triangle), 1997$ (bold line is mean).

Lehmann et al. (2001), in mixed swards with a low N application rate, white clover performs better if rather long intervals between harvests are allowed. Holliday and Wilman (1965), Reid (1970), Boxem (1973), Van Steenbergen (1977), Sibma and Alberda (1980) and Wieringa et al. (1980) emphasized the importance of the cutting regime adopted in studying the yield response of grass/white clover swards to $\mathrm{N}$ applications. A yield-based cutting schedule combined with good establishment and growing opportunities for white clover is a prerequisite to an agronomically significant and a practically oriented image of the yield response of grasslands to applied $\mathrm{N}$.

Linehan and Lowe (1960) illustrated the differences in herbage yield as well as the yield response to $\mathrm{N}$ between first and subsequent seasons of newly established grasslands, owing to changes in the botanical composition (particularly changes in white clover content). In agreement with the findings of Jackson and Williams (1979) and Cowling (1961), the yield response to applied $\mathrm{N}$ was larger during the initial seasons of the experiment, when white clover was not yet fully established. Starting from 1997 (when white clover was well established), an increase in $\mathrm{N}$ fertilization level from 0 to $100 \mathrm{~kg} \mathrm{~N} \mathrm{ha}^{-1} \mathrm{yr}^{-1}$ resulted in an average yearly yield response of $1.30 \mathrm{Mg} \mathrm{DM} \mathrm{ha}^{-1}$ or
$13 \mathrm{~kg} \mathrm{DM} \mathrm{kg}^{-1}$ applied $\mathrm{N}$. This response to applied $\mathrm{N}$ is lower than in ryegrass-dominated swards (Hopkins et al., 1995; Frame et al., 1998; Hopkins, 2000) but corresponds quite well with the average yield response of grass-clover swards of $10-12 \mathrm{~kg} \mathrm{DM} \mathrm{kg}^{-1} \mathrm{~N}$ suggested by Whitehead (1995) and the values of $11 \mathrm{~kg} \mathrm{DM} \mathrm{kg}^{-1} \mathrm{~N}$ by Davies and Williams (1958), $14 \mathrm{~kg} \mathrm{DM} \mathrm{kg}^{-1} \mathrm{~N}$ by Orr and Laidlaw (1978), $16 \mathrm{~kg}$ DM $\mathrm{kg}^{-1} \mathrm{~N}$ by Laidlaw (1980) and $7 \cdot 4-11 \cdot 6 \mathrm{~kg} \mathrm{DM} \mathrm{kg}^{-1} \mathrm{~N}$ by Shils (1997). An increase in the rate of $\mathrm{N}$ application from 100 to $200 \mathrm{~kg} \mathrm{ha}^{-1} \mathrm{yr}^{-1}$ increased the average DM yield by $0.58 \mathrm{Mg} \mathrm{ha}^{-1} \mathrm{yr}^{-1}$. This represents a response of only $5 \cdot 8 \mathrm{~kg} \mathrm{DM} \mathrm{kg}^{-1} \mathrm{~N}$. Elgersma et al. (2000) and Schils (2002) also compared different $\mathrm{N}$ treatments on a newly established grass/white clover sward. Compared with the $0 \mathrm{~N}$ treatment, application of 180 or $190 \mathrm{~kg} \mathrm{~N} \mathrm{ha}^{-1} \mathrm{yr}^{-1}$ did not increase total DM yield: an increased grass DM yield was offset by a decreased white clover yield. The increase from 200 to $400 \mathrm{~kg} \mathrm{~N} \mathrm{ha}^{-1} \mathrm{yr}^{-1}$ in $\mathrm{N}$ fertilizer applied increased the yield by $2.11 \mathrm{Mg} \mathrm{DM} \mathrm{ha}^{-1} \mathrm{yr}^{-1}$, corresponding to a response of $10.6 \mathrm{~kg} \mathrm{DM} \mathrm{kg}^{-1} \mathrm{~N}$.

When optimizing $\mathrm{N}$ fertilization from an economic point of view, it is important to know the $\mathrm{N}$ rate limit above which the resulting yield increase does not pay for the extra $\mathrm{N}$ input (Lantinga et al., 1987). According 


\begin{tabular}{lccccc}
\hline & \multicolumn{4}{c}{ N rate $\left(\mathbf{k g ~ h a}^{-\mathbf{1}} \mathbf{y r}^{-\mathbf{l}}\right)$} & \multirow{2}{*}{$\begin{array}{c}\text { Significance } \\
\text { of N rate }\end{array}$} \\
\cline { 2 - 5 } Year & $\mathbf{0}$ & $\mathbf{1 0 0}$ & $\mathbf{2 0 0}$ & $\mathbf{4 0 0}$ & $* * *$ \\
\hline 1995 & $55 \cdot 8^{\mathrm{c}}$ & $84 \cdot 6^{\mathrm{b}}$ & $89 \cdot 4^{\mathrm{b}}$ & $95 \cdot 7^{\mathrm{a}}$ & $* * *$ \\
1996 & $48 \cdot 9^{\mathrm{d}}$ & $80 \cdot 0^{\mathrm{c}}$ & $94 \cdot 9^{\mathrm{b}}$ & $108 \cdot 2^{\mathrm{a}}$ & $* * *$ \\
1997 & $73 \cdot 7^{\mathrm{c}}$ & $79 \cdot 8^{\mathrm{c}}$ & $91 \cdot 2^{\mathrm{b}}$ & $105 \cdot 8^{\mathrm{a}}$ & $* * *$ \\
1998 & $76 \cdot 6^{\mathrm{b}}$ & $80 \cdot 3^{\mathrm{b}}$ & $80 \cdot 4^{\mathrm{b}}$ & $103 \cdot 0^{\mathrm{a}}$ & $* * *$ \\
1999 & $58 \cdot 6^{\mathrm{c}}$ & $70 \cdot 1^{\mathrm{b}}$ & $68 \cdot 4^{\mathrm{b}}$ & $77 \cdot 7^{\mathrm{a}}$ & $* *$ \\
2000 & $68 \cdot 3^{\mathrm{c}}$ & $71 \cdot 4^{\mathrm{c}}$ & $77 \cdot 8^{\mathrm{b}}$ & $84 \cdot 7^{\mathrm{a}}$ & $* * *$ \\
Total 1995-2000 & $382 \cdot 1^{\mathrm{c}}$ & $466 \cdot 3^{\mathrm{b}}$ & $502 \cdot 1^{\mathrm{b}}$ & $575 \cdot 1^{\mathrm{a}}$ & $* * *$ \\
Average 1995-2000 & $63 \cdot 7^{\mathrm{c}}$ & $77 \cdot 7^{\mathrm{b}}$ & $83 \cdot 7^{\mathrm{b}}$ & $95 \cdot 9^{\mathrm{a}}$ & $* * *$ \\
Relative to 400 N & $0 \cdot 664$ & $0 \cdot 811$ & $0 \cdot 873$ & $1 \cdot 00$ & \\
Total 1997-2000 & $277 \cdot 1^{\mathrm{c}}$ & $301 \cdot 3^{\mathrm{bc}}$ & $317 \cdot 8^{\mathrm{b}}$ & $370 \cdot 9^{\mathrm{a}}$ & $* * *$ \\
Average 1997-2000 & $69 \cdot 3$ & $75 \cdot 3$ & $79 \cdot 5$ & $92 \cdot 7$ & $* * *$ \\
Relative to 400 N & $0 \cdot 747$ & $0 \cdot 812$ & $0 \cdot 857$ & $1 \cdot 00$ & \\
\hline
\end{tabular}

Within one row, values with different letters are significantly different at $\alpha=0.05$ (Newman-Keuls test).

$* *, P<0.01 ; * * *, P<0.001$.

to Neeteson and Wadman (1987), the N level at which the herbage response falls to the cost value ratio (cvr) is the economic optimum. When maize silage was considered as a potential forage to purchase in replacement of grass silage, and with local Flemish prices (Anonymous, 2000b), the resulting critical cvr was:

$$
\begin{aligned}
\mathrm{cvr} & =\frac{\text { Cost of } 1 \mathrm{~kg} \text { of mineral fertilizer } \mathrm{N} \text { (application included) }}{\text { Purchase price of } 1 \mathrm{~kg} \text { of silage maize DM }} \\
& =\frac{€ 0.625}{€ 0.062}=10 € .
\end{aligned}
$$

This value of 10 also corresponds to the critical response limit applied by Morrison et al. (1980). With this critical value, the increase of $\mathrm{N}$ application from 0 to $100 \mathrm{~kg} \mathrm{ha}^{-1} \mathrm{yr}^{-1}$ was economically justified during the growing seasons of 1997, 1998, 1999 and 2000. A further increase to $200 \mathrm{~kg} \mathrm{~N} \mathrm{ha}^{-1} \mathrm{yr}^{-1}$ was not an economic option. Increasing the $\mathrm{N}$ application from 0 to $400 \mathrm{~kg} \mathrm{~N} \mathrm{ha}^{-1} \mathrm{yr}^{-1}$ was economically justified as the response of $10 \mathrm{~kg} \mathrm{DM} \mathrm{kg}^{-1} \mathrm{~N}$ was met again. Possibly even more $\mathrm{N}$ could have resulted in a still higher response, as the grass yield under mowing management in Western Europe can continue to respond significantly up to $400-700 \mathrm{~kg} \mathrm{~N} \mathrm{ha}^{-1} \mathrm{yr}^{-1}$, depending on soil type and growing conditions ('t Mannetje and Jarvis, 1990). Behaeghe and Carlier (1973) found that even up to $600 \mathrm{~kg} \mathrm{~N} \mathrm{ha}^{-1} \mathrm{yr}^{-1}$ the yield response did not drop below $10 \mathrm{~kg} \mathrm{DM} \mathrm{kg}^{-1} \mathrm{~N}$ on the Melle experimental site. Morrison et al. (1980), using a marginal profitability of $10 \mathrm{~kg} \mathrm{DM} \mathrm{kg}^{-1} \mathrm{~N}$, found average optimum $\mathrm{N}$ rates between 388 and $530 \mathrm{~kg} \mathrm{ha}^{-1} \mathrm{yr}^{-1}$ in mowed perennial ryegrass plots. Assuming a marginal profitability of $7 \cdot 5 \mathrm{~kg} \mathrm{DM} \mathrm{kg}^{-1} \mathrm{~N}$, Prins (1983) found an average optimum $\mathrm{N}$ rate of $420 \mathrm{~kg} \mathrm{ha}^{-1} \mathrm{yr}^{-1}$ (range of 360-
$520 \mathrm{~kg} \mathrm{ha}^{-1} \mathrm{yr}^{-1}$ ) on Dutch sand and clay soils. Deenen (1994) found an average optimum $\mathrm{N}$ rate of $430 \mathrm{~kg} \mathrm{ha}^{-1} \mathrm{yr}^{-1}$ on sandy soils.

\section{Herbage net energy yield}

Table 4 summarizes the net energy yields (NEL) in the cutting experiment. The average yield of $95.9 \mathrm{GJ}$ NEL $\mathrm{ha}^{-1}$ for the $400 \mathrm{~N}$ treatment is high, but corresponds well with the findings of Deenen and Lantinga (1993) and Lantinga and Groot (1996). Relative to the 6-year NEL yield of the $400 \mathrm{~N}$ treatment, the $200 \mathrm{~N}, 100 \mathrm{~N}$ and $0 \mathrm{~N}$ yields were $0.87,0.81$ and 0.66 respectively. These relative values correspond well to those found when comparing DM yields, indicating that the average feed energy contents of the herbage on the four $\mathrm{N}$ treatments were comparable. On average, the $100 \mathrm{~N}$ plots outyielded the $0 \mathrm{~N}$ plots by 14.0 GJ NEL ha ${ }^{-1} \mathrm{yr}^{-1}$. Increasing $\mathrm{N}$ fertilization from 100 to $200 \mathrm{~kg} \mathrm{ha}^{-1}$ $\mathrm{yr}^{-1}$ resulted in a smaller yield increase of $6.0 \mathrm{GJ}$ NEL $\mathrm{ha}^{-1} \mathrm{yr}^{-1}$. Over the 6-year period of the experiment, the yields of the $100 \mathrm{~N}$ and $200 \mathrm{~N}$ treatments were not significantly different. A further increase in the $\mathrm{N}$ level from 200 to $400 \mathrm{~kg} \mathrm{ha}^{-1} \mathrm{yr}^{-1}$ again resulted in a significant increase in feed energy yield of $12 \cdot 2$ GJ NEL ha ${ }^{-1} \mathrm{yr}^{-1}$. Considering the period with full white clover development (from 1997 onwards), the average yield responses to applied $\mathrm{N}$ for the $\mathrm{N}$ levels of 0-100, 100-200 and 200-400 $\mathrm{kg} \mathrm{ha}^{-1} \mathrm{yr}^{-1}$ were 60.5, $41 \cdot 3$ and $66 \cdot 4 \mathrm{MJ}$ NEL $\mathrm{kg}^{-1} \mathrm{~N}$ respectively.

Following Neeteson and Wadman (1987) again, the critical yield response was determined as the ratio of the local cost of $1 \mathrm{~kg} \mathrm{~N}$ in mineral fertilizer $(€ 0 \cdot 625)$ to the purchase price of $1 \mathrm{MJ}$ NEL in silage maize $(€ 0 \cdot 011)$. 
This resulted in a critical yield response value of $57 \mathrm{MJ}$ NEL kg ${ }^{-1} \mathrm{~N}$ applied. At this critical cvr, increasing the $\mathrm{N}$-fertilization rate from 0 to $100 \mathrm{~kg} \mathrm{ha}^{-1} \mathrm{yr}^{-1}$ was an economically sensible decision. As a further increase to $200 \mathrm{~kg} \mathrm{~N} \mathrm{ha}^{-1} \mathrm{yr}^{-1}$ was reflected in a yield response of only $41 \cdot 3 \mathrm{MJ} \mathrm{NEL} \mathrm{kg} \mathrm{kg}^{-1} \mathrm{~N}$ applied, increasing $\mathrm{N}$ fertilization from 100 to $200 \mathrm{~kg} \mathrm{ha}^{-1} \mathrm{yr}^{-1}$ was not economic. However, increasing from 100 to $400 \mathrm{~kg} \mathrm{~N} \mathrm{ha}^{-1} \mathrm{yr}^{-1}$ resulted in an increase of $58 \mathrm{MJ}$ $\mathrm{NEL} \mathrm{kg}^{-1} \mathrm{~N}$ (a response just reaching the critical cvr) and hence was economically justified.

These findings reflect the importance of white clover presence in the sward for judging optimal $\mathrm{N}$ fertilizer use. Applying $100 \mathrm{~kg} \mathrm{~N}^{-1} \mathrm{yr}^{-1}$ (in two spring dressings of $50 \mathrm{~kg} \mathrm{~N} \mathrm{ha}^{-1}$ ) resulted in a significant and economically justified increase in DM as well as in NEL yield compared with the $0 \mathrm{~N}$ plots. Morrison et al. (1983) highlighted the potential of moderate $\mathrm{N}$ rates to overcome seasonal deficiencies in production of grass/ white clover swards but an increased herbage production must always be weighed against the depressive effects on white clover performance when increased $\mathrm{N}$ fertilizer use is considered (Frame and Boyd, 1986, 1987; Frame and Newbould, 1986). Compared with the $0 \mathrm{~N}$ plots, the white clover content of the $100 \mathrm{~N}$ sward was somewhat depressed, although not significantly (Table 3). Compared with the $100 \mathrm{~N}$ plots, the addition of $\mathrm{N}$ fertilizer to the $200 \mathrm{~N}$ plots clearly reduced the white clover content, but the resulting extra grass growth compensated for the yield loss through the disappearance of white clover and the net yield result of the extra $100 \mathrm{~kg} \mathrm{~N} \mathrm{ha}^{-1}$ was not significant. This illustrates that when white clover is given high priority, $\mathrm{N}$ fertilization should only be used strategically during spring and at low levels (Laidlaw, 1980, 1984; Frame and Boyd, 1987; Baars, 2001; Schils, 2002). On the $400 \mathrm{~N}$ plots, white clover nearly disappeared and the high NEL yield was the result of rapid grass growth at high $\mathrm{N}$ availability from mineral fertilizer.

These results suggest a two-track $\mathrm{N}$ fertilization management: either low $\mathrm{N}$ use (no more than $100 \mathrm{~kg} \mathrm{~N} \mathrm{ha}^{-1} \mathrm{yr}^{-1}$ ) to take maximum advantage of white clover; or use fertilizer $\mathrm{N}$ intensively, knowing that a fertilizer level of $400 \mathrm{~kg} \mathrm{~N} \mathrm{ha}^{-1} \mathrm{yr}^{-1}$ (or even more) is economically justified. A similar two-track decision schedule was also indicated by Schils (2002). Reid (1983) concluded that the $\mathrm{N}$ rates required for an annual yield of $12 \mathrm{Mg} \mathrm{DM} \mathrm{ha}{ }^{-1}$ were $340 \mathrm{~kg} \mathrm{ha}^{-1}$ in a pure perennial ryegrass sward and $140 \mathrm{~kg} \mathrm{ha}^{-1}$ on a perennial ryegrass/white clover sward. The statement of Armitage and Templeman (1964) that the use of fertilizer $\mathrm{N}$ should be preferred to a reliance on white clover to obtain the highest DM yields is also in line with the results.

\section{Nitrogen yields}

Table 5 describes the $\mathrm{N}$ yields of the cut grassland. The $\mathrm{N}$ yield of the $400 \mathrm{~N}$ treatment (on average $429 \mathrm{~kg} \mathrm{ha}^{-1} \mathrm{yr}^{-1}$ ) was always significantly higher than the $\mathrm{N}$ yields on the other treatments. Compared with $100 \mathrm{~N}$ treatment, the $200 \mathrm{~N}$ treatment had a significantly higher N yield in 1995 and 1996. However, from 1997 onwards, the $\mathrm{N}$ yields of the $0 \mathrm{~N}, 100 \mathrm{~N}$ and $200 \mathrm{~N}$ treatments did not differ significantly except that the $\mathrm{N}$ yield of the $0 \mathrm{~N}$ treatment was significantly lower in 2000. In 1995 and 1996, when

Table 5 Nitrogen yields $\left(\mathrm{kg} \mathrm{ha}^{-1} \mathrm{yr}^{-1}\right)$ at a range of $\mathrm{N}$ fertilizer rates in the cutting experiment.

\begin{tabular}{lccccc}
\hline & \multicolumn{4}{c}{ N rate $\left(\mathbf{k g ~ h a}^{-\mathbf{1}} \mathbf{y r}^{-\mathbf{1}}\right)$} & Significance \\
\cline { 2 - 5 } Year & $\mathbf{0}$ & $\mathbf{1 0 0}$ & $\mathbf{2 0 0}$ & $\mathbf{4 0 0}$ & of rate \\
\hline 1995 & $154^{\mathrm{d}}$ & $290^{\mathrm{c}}$ & $323^{\mathrm{b}}$ & $456^{\mathrm{a}}$ & $* * *$ \\
1996 & $150^{\mathrm{d}}$ & $266^{\mathrm{c}}$ & $299^{\mathrm{b}}$ & $509^{\mathrm{a}}$ & $* * *$ \\
1997 & $302^{\mathrm{b}}$ & $291^{\mathrm{b}}$ & $276^{\mathrm{b}}$ & $416^{\mathrm{a}}$ & $* * *$ \\
1998 & $281^{\mathrm{b}}$ & $274^{\mathrm{b}}$ & $294^{\mathrm{b}}$ & $441^{\mathrm{a}}$ & $* * *$ \\
1999 & $237^{\mathrm{b}}$ & $261^{\mathrm{b}}$ & $243^{\mathrm{b}}$ & $292^{\mathrm{a}}$ & $* *$ \\
2000 & $287^{\mathrm{c}}$ & $350^{\mathrm{b}}$ & $365^{\mathrm{b}}$ & $461^{\mathrm{a}}$ & $* * *$ \\
Total 1995-2000 & $1411^{\mathrm{c}}$ & $1732^{\mathrm{b}}$ & $1799^{\mathrm{b}}$ & $2576^{\mathrm{a}}$ & $* * *$ \\
Average 1995-2000 & $235^{\mathrm{c}}$ & $289^{\mathrm{b}}$ & $300^{\mathrm{b}}$ & $429^{\mathrm{a}}$ & $* * *$ \\
Relative to 400 N & $0 \cdot 548$ & $0 \cdot 672$ & $0 \cdot 698$ & $1 \cdot 00$ & \\
Total 1997-2000 & $1107^{\mathrm{b}}$ & $1176^{\mathrm{b}}$ & $1178^{\mathrm{b}}$ & $1610^{\mathrm{a}}$ & $* * *$ \\
Average 1997-2000 & $277^{\mathrm{b}}$ & $294^{\mathrm{b}}$ & $295^{\mathrm{b}}$ & $403^{\mathrm{a}}$ & $* * *$ \\
Relative to 400 N & $68 \cdot 7$ & $73 \cdot 0$ & $73 \cdot 2$ & 100 & \\
\hline
\end{tabular}

Within one row, values with different letters are significantly different at $P<0.05$ (Newman-Keuls test).

$* *, P<0.01 ; * * *, P<0.001$. 
white clover was not yet established, the $\mathrm{N}$ yields on the $0 \mathrm{~N}$ plots were low. From 1997 onwards and owing to the rising white clover content, these $\mathrm{N}$ yields increased and were higher than those from $L$. perenne-dominated swards without $\mathrm{N}$ fertilization (Hopkins et al., 1995). Compared with the DM yields, the relative $\mathrm{N}$ yields show a greater difference between the $400 \mathrm{~N}$ and the other treatments. This indicates a higher $\mathrm{N}$ concentration of the herbage harvested at the highest $\mathrm{N}$ rate. Figure 5 confirms this. The herbage on the $400 \mathrm{~N}$ treatment contained about $26 \mathrm{~g} \mathrm{~N} \mathrm{~kg}^{-1} \mathrm{DM}$ for cuts between 3 and $5 \mathrm{Mg} \mathrm{DM} \mathrm{ha}{ }^{-1}$. In the same yield range, an average $\mathrm{N}$ concentration of $20 \mathrm{~g} \mathrm{~kg}^{-1} \mathrm{DM}$ was observed for the $0 \mathrm{~N}, 100 \mathrm{~N}$ and $200 \mathrm{~N}$ treatments. In 1995 and 1996 there were low $\mathrm{N}$ concentrations on the $0 \mathrm{~N}$ treatment (14-17 $\mathrm{g} \mathrm{N} \mathrm{kg}^{-1} \mathrm{DM}$ ) but with increasing white clover development these contents rose to averages of 20 (cut at $4 \mathrm{Mg} \mathrm{DM} \mathrm{ha}^{-1}$ ) to 29 (cut at $2 \mathrm{Mg} \mathrm{DM} \mathrm{ha}^{-1}$ ) $\mathrm{g} \mathrm{N} \mathrm{kg}^{-1} \mathrm{DM}$.

\section{Residual soil nitrate- $N$}

The amounts of residual soil nitrate- $\mathrm{N}\left(\mathrm{N}_{\text {res }}\right)$ are presented in Figure 6. The relatively low amounts of $\mathrm{N}_{\text {res }}$ for cut grassland correspond well with other studies. Alberda (1971) concluded that high amounts of $\mathrm{N}$ fertilizer could be applied to cut grassland without risk of excessive nitrate leaching. From the results of this study (and accepting the $90 \mathrm{~kg} \mathrm{ha}^{-1}$ threshold on residual $\mathrm{N}$ ), it is concluded that, at least up to an application of $400 \mathrm{~kg} \mathrm{~N} \mathrm{ha}^{-1} \mathrm{yr}^{-1}$, no excessive leaching should occur. This is in agreement with Prins (1983) who concluded that up to the economically optimal $\mathrm{N}$ rate, the risks of $\mathrm{N}$-leaching from cut swards are minimal. Even if we assume an arbitrary threshold value of only $70 \mathrm{~kg}$ residual nitrate- $\mathrm{N} \mathrm{ha}^{-1}$, fertilizing at the economically optimal $\mathrm{N}$ rate would cause no excessive amounts of residual soil nitrate.

\section{Grazing experiment}

\section{Botanical changes}

Although no statistically significant differences were observed, the frequency of white clover at the start of the 1998 grazing season was higher on the $0 \mathrm{~N}$ treatment than on the $200 \mathrm{~N}$ and $400 \mathrm{~N}$ treatments (Table 6). However, white clover contents did not increase to the same extent as in the cutting experiment, except at $400 \mathrm{~N}$. The lower presence of white clover on grazed grassland is consistent with the findings of Brockman and Wolton (1963) and was probably due to the recirculation of $\mathrm{N}$ through the heifers. The decrease of L. perenne in the $0 \mathrm{~N}$ plots was not just due to an increase in the content of white

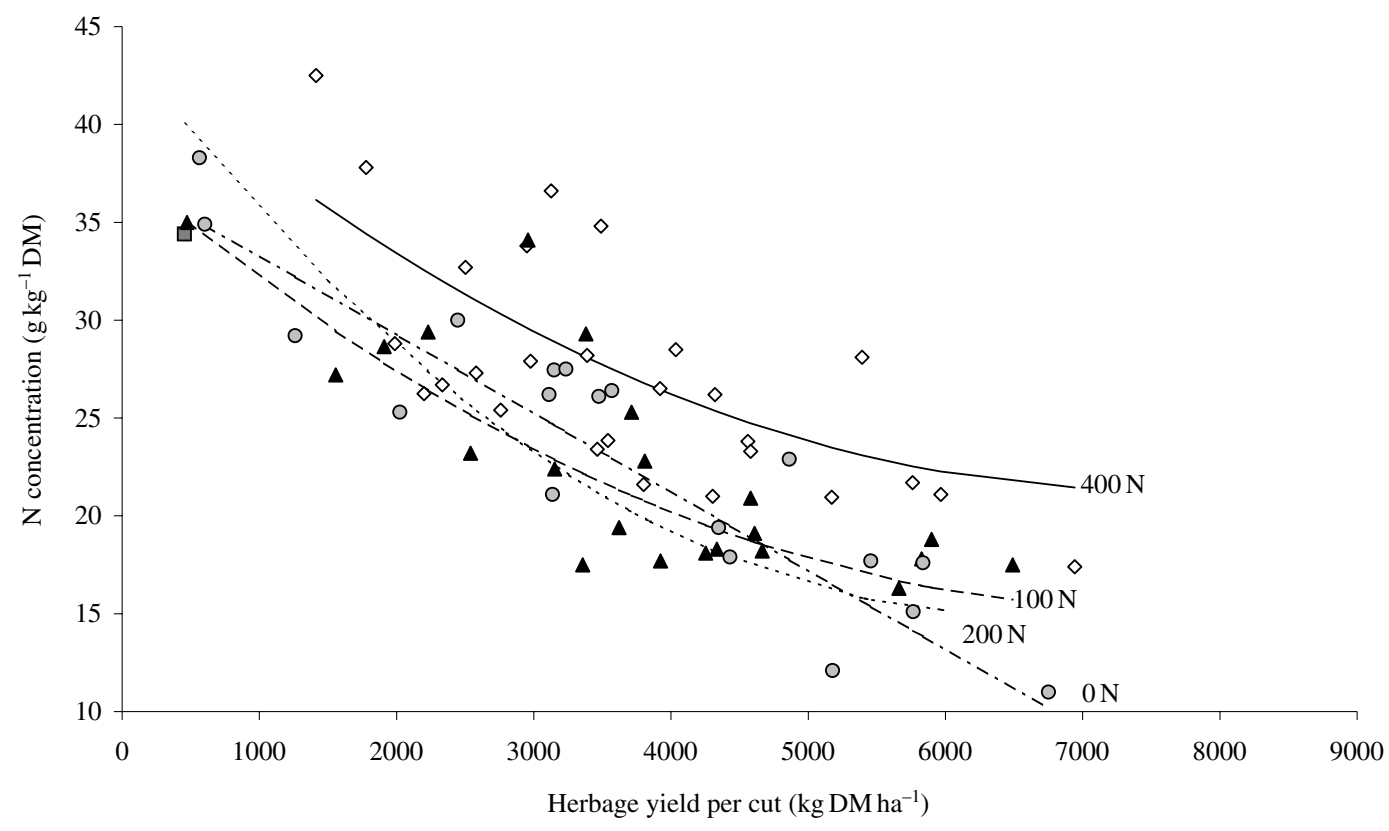

Figure $5 \mathrm{~N}$ concentration of the harvested herbage for each cut of the four $\mathrm{N}$ treatments $(\diamond, 400 \mathrm{~N} ; \square, 200 \mathrm{~N} ; \boldsymbol{\Delta}, 100 \mathrm{~N}$ and $0,0 \mathrm{~N})$. 


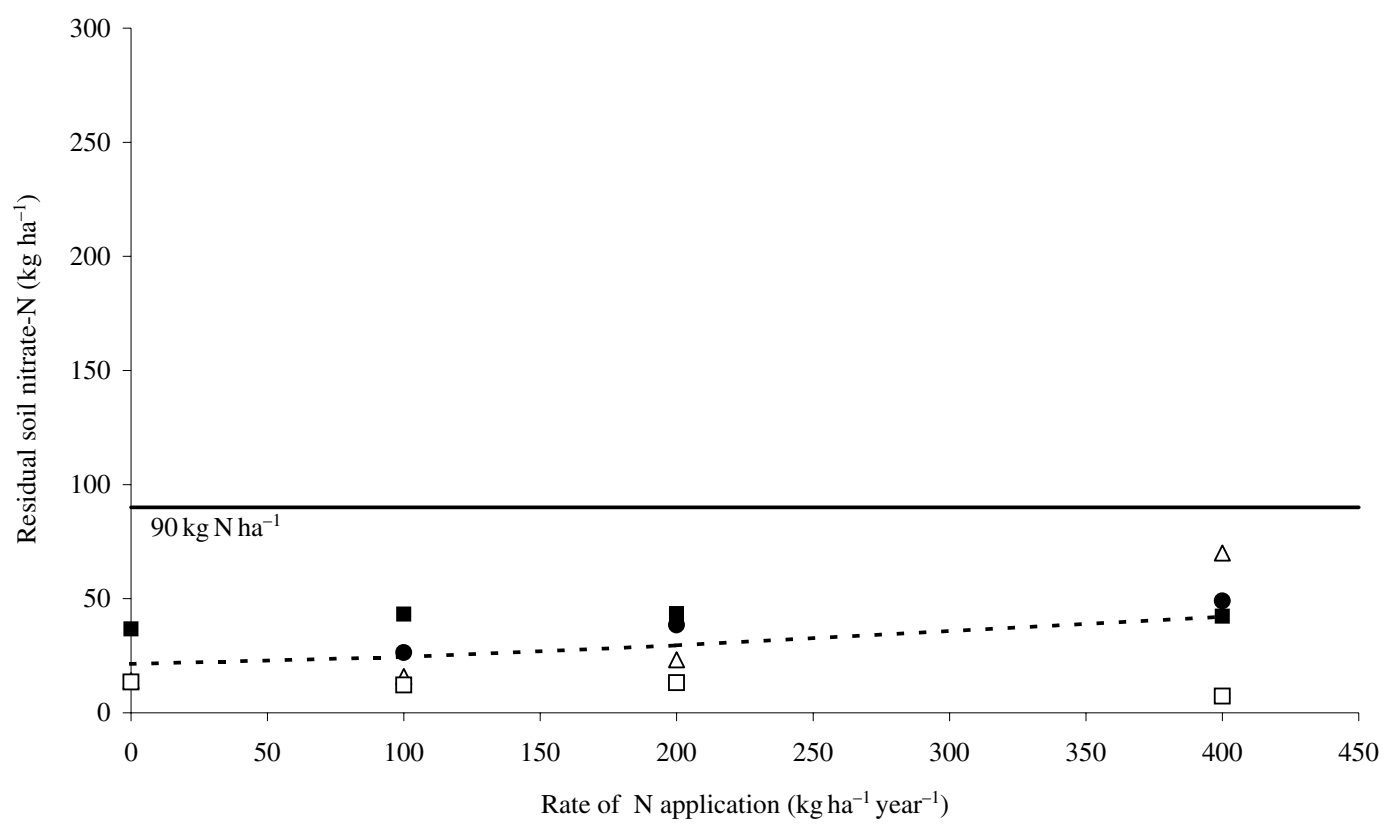

Figure 6 Residual soil nitrate- $N\left(\mathrm{~kg} \mathrm{ha}^{-1} ; 0-90 \mathrm{~cm}\right)$ in the cut swards after the growing seasons of $1996(\triangle), 1997(\mathbf{\square}), 1998(\square)$ and 1999 (Mean value is given by the dashed line).

Table 6 Importance percentage of plant species and frequency of Trifolium repens $L$. in the swards receiving the $N$ fertilizer application rates in the grazing experiment.

\begin{tabular}{|c|c|c|c|c|}
\hline \multirow[b]{2}{*}{ Species } & \multicolumn{3}{|c|}{$\mathrm{N}$ rate $\left(\mathrm{kg} \mathrm{ha}^{-1} \mathrm{yr}^{-1}\right)$} & \multirow{2}{*}{$\begin{array}{c}\text { Significance } \\
\text { of } N \text { rate }\end{array}$} \\
\hline & $\mathbf{0}$ & 200 & 400 & \\
\hline \multicolumn{5}{|c|}{ Importance percentage on 15 March 1995} \\
\hline Lolium perenne L. & & $35 \cdot 9$ & & \\
\hline Poa trivialis $\mathrm{L}$. & & $43 \cdot 4$ & & \\
\hline Agrostis spp. & & $9 \cdot 6$ & & \\
\hline Trifolium repens $\mathrm{L}$. & & $7 \cdot 6$ & & \\
\hline \multicolumn{5}{|c|}{ Importance percentage on 27 March 1998} \\
\hline Lolium perenne L. & $26 \cdot 0^{\mathrm{b}}$ & $47 \cdot 3^{\mathrm{a}}$ & $49 \cdot 5^{\mathrm{a}}$ & * \\
\hline Poa trivialis $\mathrm{L}$. & $33 \cdot 1$ & $32 \cdot 2$ & $29 \cdot 8$ & NS \\
\hline Agrostis spp. & $22 \cdot 3$ & $6 \cdot 8$ & $8 \cdot 4$ & NS \\
\hline Trifolium repens $\mathrm{L}$. & $14 \cdot 4$ & $11 \cdot 4$ & $8 \cdot 5$ & NS \\
\hline \multicolumn{5}{|c|}{ Frequency (\%) of Trifolium repens $\mathrm{L}$. } \\
\hline 27 March 1998 & $59 \cdot 3$ & $36 \cdot 0$ & $30 \cdot 0$ & NS \\
\hline
\end{tabular}

Within one year, values with different letters are significantly different at $P<0.05$ (Newman-Keuls test).

$*, P<0 \cdot 05 ;$ NS, non-significant.

clover but also due to an expansion in the content of Agrostis species. In March 1998, the presence of L. perenne in the $200 \mathrm{~N}$ and $400 \mathrm{~N}$ plots $(47 \%$ and $50 \%$ respectively) had increased compared with the initial year of 1995 (36\%) (Table 6).

\section{Herbage net energy yield}

The NEL yields of the $0 \mathrm{~N}, 200 \mathrm{~N}$ and $400 \mathrm{~N}$ treatments are summarized in Table 7 . The average yields of 71-74 GJ NEL ha $\mathrm{yr}^{-1}$ on the $200 \mathrm{~N}$ and $400 \mathrm{~N}$ grazed swards correspond well with the values of Deenen and Lantinga (1993), Lantinga and Groot (1996), Berentsen et al. (2000) and Mayne et al. (2000). The 31-year (1969-99) average yield on adjacent grazed permanent grassland at the Melle experimental site was $75 \cdot 1$ GJ NEL ha ${ }^{-1} \mathrm{yr}^{-1}$ (Nevens and Reheul, 2003). There was a high variability in the NEL yield of the grazed grassland. The highest yield was 84.4 GJ NEL ha ${ }^{-1}$ in 1997 and the lowest yield was $5.3 \mathrm{GJ} \mathrm{NEL} \mathrm{ha}^{-1}$ in 1999. This high between-year yield variability on grazed grasslands, often larger than differences in the rate of $\mathrm{N}$ fertilizer application, is not new (Anonymous, 1999).

In three of four grazing seasons, the $200 \mathrm{~N}$ treatment resulted in a significantly higher NEL yield than the $0 \mathrm{~N}$ treatment but no significant yield difference between the $200 \mathrm{~N}$ and the $400 \mathrm{~N}$ paddocks was observed. Increasing the rate of $\mathrm{N}$ application from 0 to $200 \mathrm{~kg} \mathrm{ha}^{-1} \mathrm{yr}^{-1}$ on this grazed grassland was economically justified as the average yield response of $110 \mathrm{MJ} \mathrm{NEL} \mathrm{kg}{ }^{-1} \mathrm{~N}$ exceeded the critical cvr of $57 \mathrm{MJ}$ NEL kg-1 $\mathrm{N}$. A further increase in $\mathrm{N}$ fertilizer rate from 200 to $400 \mathrm{~kg} \mathrm{ha}^{-1} \mathrm{yr}^{-1}$ was not economically 
Table 7 Net energy yields (GJ NEL ha ${ }^{-1} \mathrm{yr}^{-1}$ ) at a range of $\mathrm{N}$ fertilizer rates of herbage in the grazing experiment

\begin{tabular}{|c|c|c|c|c|}
\hline \multirow[b]{2}{*}{ Year } & \multicolumn{3}{|c|}{$\mathrm{N}$ rate $\left(\mathrm{kg} \mathrm{ha}^{-1} \mathrm{yr}^{-1}\right)$} & \multirow{2}{*}{$\begin{array}{c}\text { Significance } \\
\text { of } N \text { rate }\end{array}$} \\
\hline & $\mathbf{0}$ & 200 & 400 & \\
\hline 1996 & $45 \cdot 4^{\mathrm{b}}$ & $77 \cdot 5^{\mathrm{a}}$ & $84 \cdot 1^{\mathrm{a}}$ & * \\
\hline 1997 & $53 \cdot 2^{\mathrm{b}}$ & $84 \cdot 1^{\mathrm{a}}$ & $84 \cdot 4^{\mathrm{a}}$ & * \\
\hline 1998 & $59 \cdot 6^{\mathrm{a}}$ & $69 \cdot 8^{\mathrm{a}}$ & $68 \cdot 4^{\mathrm{a}}$ & NS \\
\hline 1999 & $39 \cdot 1^{\mathrm{b}}$ & $53 \cdot 5^{\mathrm{a}}$ & $58 \cdot 3^{a}$ & $*$ \\
\hline Total 1996-99 & $197 \cdot 2^{\mathrm{b}}$ & $284 \cdot 9^{\mathrm{a}}$ & $295 \cdot 1^{a}$ & * \\
\hline Average 1996-99 & $49 \cdot 3^{\mathrm{b}}$ & $71 \cdot 2^{\mathrm{a}}$ & $73 \cdot 8^{\mathrm{a}}$ & * \\
\hline Relative to $400 \mathrm{~N}$ & $0 \cdot 668$ & 0.965 & $1 \cdot 00$ & \\
\hline
\end{tabular}

Within one row, values with different letters are significantly different at $P<0.05$ (Newman-Keuls test).

$*, P<0.05$; NS, non-significant.

justified, as the yield response was only 13 MJ NEL kg ${ }^{-1}$ N. Jackson and Williams (1979) also found no significant response in grazed grassland yields when the $\mathrm{N}$ rate was increased from 200 to $400 \mathrm{~kg} \mathrm{ha}^{-1} \mathrm{yr}^{-1}$. The yield response of grazed grassland in this higher $\mathrm{N}$ application range is well below the yield response of cut grassland (Deenen, 1994; Whitehead, 1995). The results reported here are in agreement with those of Deenen (1994) and Jackson and Williams (1979), who estimated that the optimum $\mathrm{N}$ application rate under grazing is some $200 \mathrm{~kg} \mathrm{ha}^{-1} \mathrm{yr}^{-1}$ less than under cutting. A study in Germany suggested that the economically optimum $\mathrm{N}$ rate for grassland grazed by heifers is no more than $100 \mathrm{~kg} \mathrm{ha}^{-1} \mathrm{yr}^{-1}$ (Anonymous, 1999).

Compared with the cut plots (1996-99), the grazed $0 \mathrm{~N}, 200 \mathrm{~N}$ and $400 \mathrm{~N}$ plots yielded 0.77, 0.85 and 0.75 of NEL respectively. Lantinga et al. (1987) obtained similar results with an approximately $0 \cdot 20$ lower yield under grazing (at $\mathrm{N}$ fertilizer rates of 214 and $427 \mathrm{~kg} \mathrm{ha}^{-1} \mathrm{yr}^{-1}$ ). The lower yields under grazing result from the higher frequency of defoliation (Sibma and Alberda, 1980) and the adverse effects on the sward through treading, selective grazing and fouling of herbage by dung (Whitehead, 1995). These adverse effects exceeded the potential positive effect of nutrient return through excreta.

As mentioned previously, the yields observed in the cutting experiment are overestimated as field and conservation losses were not taken into account. On average, field and conservation losses are estimated at $0 \cdot 15-0 \cdot 20$ of DM yield under an optimal conservation management ( $2 \mathrm{~d}$ of field drying prior to ensiling at a DM content of $350 \mathrm{~g} \mathrm{~kg}^{-1}$ (Nevens and Reheul, 1999). This brings the net yield under cutting close to the yield under grazing.
Table $8 \mathrm{~N}$ yields $\left(\mathrm{kg} \mathrm{ha}^{-1} \mathrm{yr}^{-1}\right)$ at a range of $\mathrm{N}$ fertilizer rates in the grazing experiment.

\begin{tabular}{lccc}
\hline & \multicolumn{3}{c}{ N rate $\left(\mathbf{k g ~ h a}^{-\mathbf{1}} \mathbf{y r}^{-\mathbf{1}}\right)$} \\
\cline { 2 - 4 } Year & $\mathbf{0}$ & $\mathbf{2 0 0}$ & $\mathbf{4 0 0}$ \\
\hline 1996 & $10 \cdot 1$ & $17 \cdot 3$ & $18 \cdot 7$ \\
1997 & $21 \cdot 1$ & $33 \cdot 3$ & $33 \cdot 4$ \\
1998 & $19 \cdot 1$ & $22 \cdot 3$ & $21 \cdot 9$ \\
1999 & $18 \cdot 5$ & $26 \cdot 8$ & $27 \cdot 7$ \\
Total 1996-99 & $68 \cdot 8$ & $99 \cdot 7$ & $101 \cdot 7$ \\
Average 1996-99 & $17 \cdot 2$ & $24 \cdot 9$ & $25 \cdot 4$ \\
Relative to 400 N & $0 \cdot 677$ & $0 \cdot 980$ & $1 \cdot 00$ \\
\hline
\end{tabular}

\section{Nitrogen yield}

The amounts of $\mathrm{N}$ deposited by the growing heifers at the end of the grazing seasons are presented in Table 8 . There are discrepancies between observed $\mathrm{N}$ yield and net energy yield (Table 7) due to betweenseason differences in initial live weight of the heifers and their liveweight gain. $\mathrm{N}$ yields only comprise the observed liveweight gain while energy yields comprise both energy needed for liveweight gain and maintenance. Heavier and/or slower-growing animals use relatively more energy for maintenance than for growing; hence they yield less $\mathrm{N}$ per unit of net energy.

The observed $\mathrm{N}$ yields were very small. A maximum $\mathrm{N}$ yield of $33 \mathrm{~kg} \mathrm{ha}^{-1} \mathrm{yr}^{-1}$ (400 $\mathrm{N}$ treatment in 1997) and average values from 1996 to 1999 of 17, 25 and $25 \mathrm{~kg} \mathrm{ha}^{-1} \mathrm{yr}^{-1}$ on the $0 \mathrm{~N}, 200 \mathrm{~N}$ and $400 \mathrm{~N}$ treatments respectively. These $\mathrm{N}$ yields represent $0 \cdot 06-0 \cdot 08$ of the yields from the cut plots. Weissbach and Ernst (1994) also reported comparable low $\mathrm{N}$ yields or translocations in grazing systems with heifers: 14$19 \mathrm{~kg} \mathrm{ha}^{-1} \mathrm{yr}^{-1}$ at $\mathrm{N}$-application rates of 0 and $330 \mathrm{~kg} \mathrm{ha}^{-1} \mathrm{yr}^{-1}$ respectively. Van der Putten and Vellinga (1996) estimated maximum $\mathrm{N}$ translocations by growing cattle of $33 \mathrm{~kg} \mathrm{ha}^{-1} \mathrm{yr}^{-1}$ at $\mathrm{N}$-application rates of 240,360 and $480 \mathrm{~kg} \mathrm{ha}^{-1} \mathrm{yr}^{-1}$ respectively.

\section{Residual soil nitrate- $N$}

On the $0 \mathrm{~N}$ treatment, the amounts of residual soil nitrate- $\mathrm{N}$ were comparable with those found on the $0 \mathrm{~N}$ treatments under cutting and were always well below $90 \mathrm{~kg} \mathrm{ha}^{-1}$ (Figure 7). On the $200 \mathrm{~N}$ grazed plots, the average of $77 \mathrm{~kg}$ residual nitrate- $\mathrm{N} \mathrm{ha}^{-1}$ came close to the threshold value; in one of the four seasons (1997) the limit was actually exceeded (99 $\mathrm{kg}$ nitrate- $\mathrm{N} \mathrm{ha}{ }^{-1}$ ). Applying $400 \mathrm{~kg} \mathrm{~N} \mathrm{ha}^{-1} \mathrm{yr}^{-1}$ on the grazed plots resulted in very high amounts of residual soil nitrate- $\mathrm{N}$, as 
after each grazing season high amounts of residual soil nitrate- $\mathrm{N}$ were left in the soil profile with up to a maximum of $289 \mathrm{~kg} \mathrm{~N} \mathrm{ha}^{-1}$ in 1996 (Figure 7). The large return of excreted $\mathrm{N}$ in local concentrations far beyond the demand of the herbage resulted in accumulation of nitrate- $\mathrm{N}$, which is prone to leaching during winter (Ball and Keeney, 1981; Deenen, 1994). If an arbitrary threshold value of only $70 \mathrm{~kg}$ residual nitrate- $\mathrm{N} \mathrm{ha}^{-1}$ is assumed, the ecologically optimum $\mathrm{N}$ fertilizer rate would be about $150 \mathrm{~kg} \mathrm{ha}^{-1}$. This optimum rate corresponds quite well with the results of the literature review (Figure 1).

Weissbach and Ernst (1994) compared grass/clover swards receiving $46 \mathrm{~kg} \mathrm{~N} \mathrm{ha}^{-1} \mathrm{yr}^{-1}$ with pure grass swards receiving $377 \mathrm{~kg} \mathrm{~N} \mathrm{ha}^{-1} \mathrm{yr}^{-1}$. The amount of inorganic $\mathrm{N}$ in the upper $100 \mathrm{~cm}$ of soil in autumn was less than $100 \mathrm{~kg} \mathrm{ha}^{-1}$ for the lower and 200 $300 \mathrm{~kg} \mathrm{ha}^{-1}$ for the higher rate of $\mathrm{N}$ fertilizer. Compared with grazing by heifers, grazing by dairy cows resulted in higher $\mathrm{N}$ removal, but did not change the amounts of residual $\mathrm{N}$.

\section{Mowing vs. grazing: environmental $\mathbf{N}$ efficiency}

The environmental efficiency (or rather inefficiency) of $\mathrm{N}$ use in herbage production was expressed as the ratio of the residual inorganic $\mathrm{N}$ in the soil at the end of the growing season and the total herbage yield (Lantinga and Groot, 1996); the lower this ratio, the more environmentally efficient is the herbage production. For the cutting experiment, NEL yields corrected for losses during the field period, at harvest and in conservation were used. According to Nevens and Reheul (1999), the observed NEL yields on the cut plots were decreased (Table 4 ) by $0 \cdot 20$. This resulted in values of 0.30 and $0.44 \mathrm{~kg}$ residual nitrate-N GJ ${ }^{-1} \mathrm{NEL}$ for the $0 \mathrm{~N}$ and $400 \mathrm{~N}$ treatments respectively (Figure 8 ). For the grazing experiment these values were 0.87 and $2.42 \mathrm{~kg}$ residual nitrate- $\mathrm{N} \mathrm{GJ}^{-1}$ NEL respectively. Restricting this study to scale of the grassland plot indicates that the environmental efficiency under grazing is three to six times lower than that under cutting.

However, cut grass still has to be fed to livestock. For both grazed and cut grassland, Figure 9 represents the ratio of total $\mathrm{N}$ output to $\mathrm{N}$ input as a measure of the global $\mathrm{N}$ use efficiency. For both systems, $\mathrm{N}$ input $\left(\mathrm{N}_{\text {in }}\right)$ is the amount of fertilizer $\mathrm{N}$ applied. For the grazed plots, $\mathrm{N}$ output $\left(\mathrm{N}_{\mathrm{out}}\right)$ is the $\mathrm{N}$ translocation in liveweight gain of the grazing heifers. For the cut plots, initial $\mathrm{N}_{\text {out }}$ is the amount of $\mathrm{N}$ translocated in the harvested herbage (including a loss of 0.20 for field and conservation losses). Adjusted values of $\mathrm{N}_{\text {out }}$ for the cut swards were calculated for two scenarios.

In the first scenario, it was assumed that, for dairy cattle, on average 0.20 of the amount of the herbage $\mathrm{N}$ intake by animals is retained in net animal production

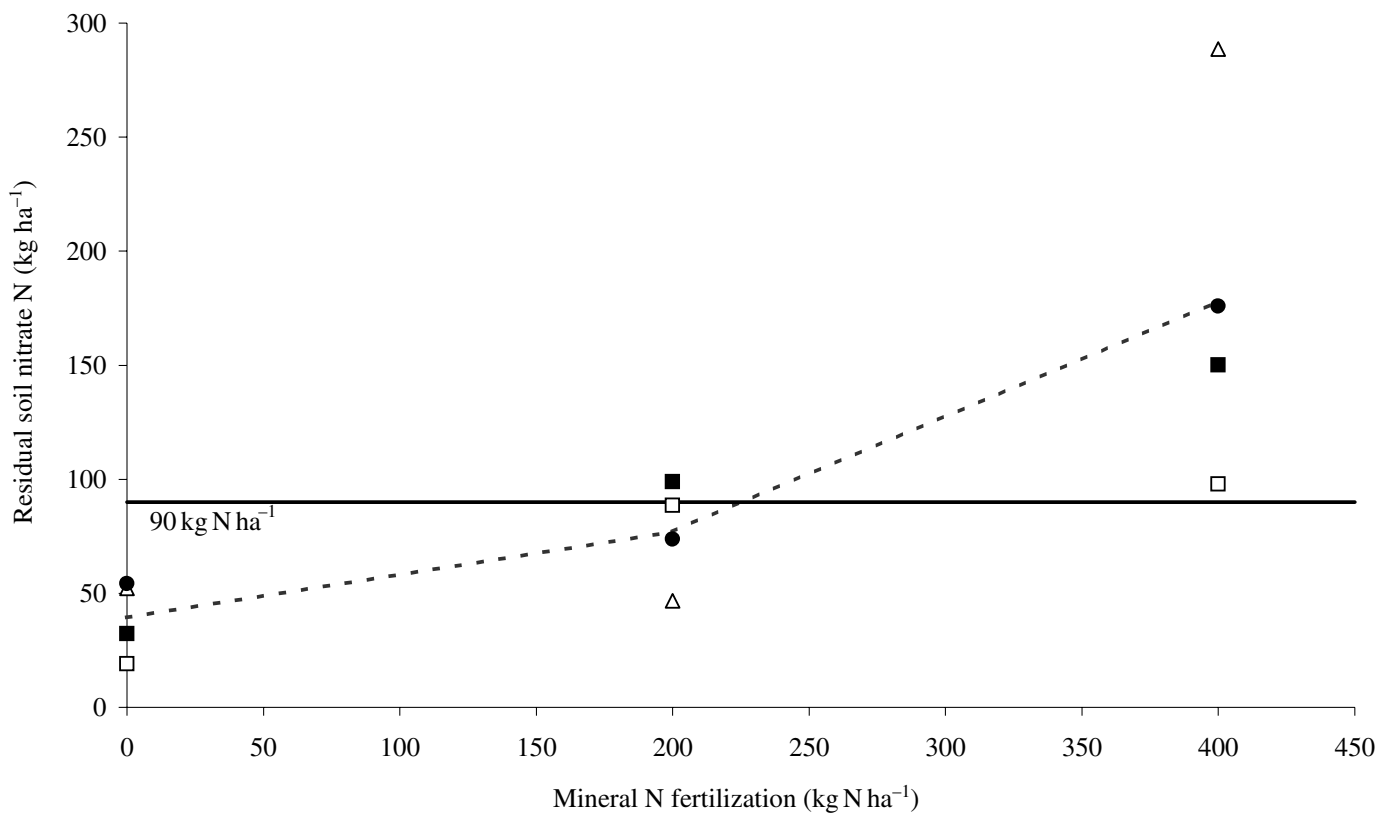

Figure 7 Residual soil nitrate- $N\left(\mathrm{~kg} \mathrm{ha}^{-1} ; 0-90 \mathrm{~cm}\right)$ in the grazed swards after the growing seasons of $1996(\triangle), 1997$ $1998(\square)$ and $1999(0)$ 


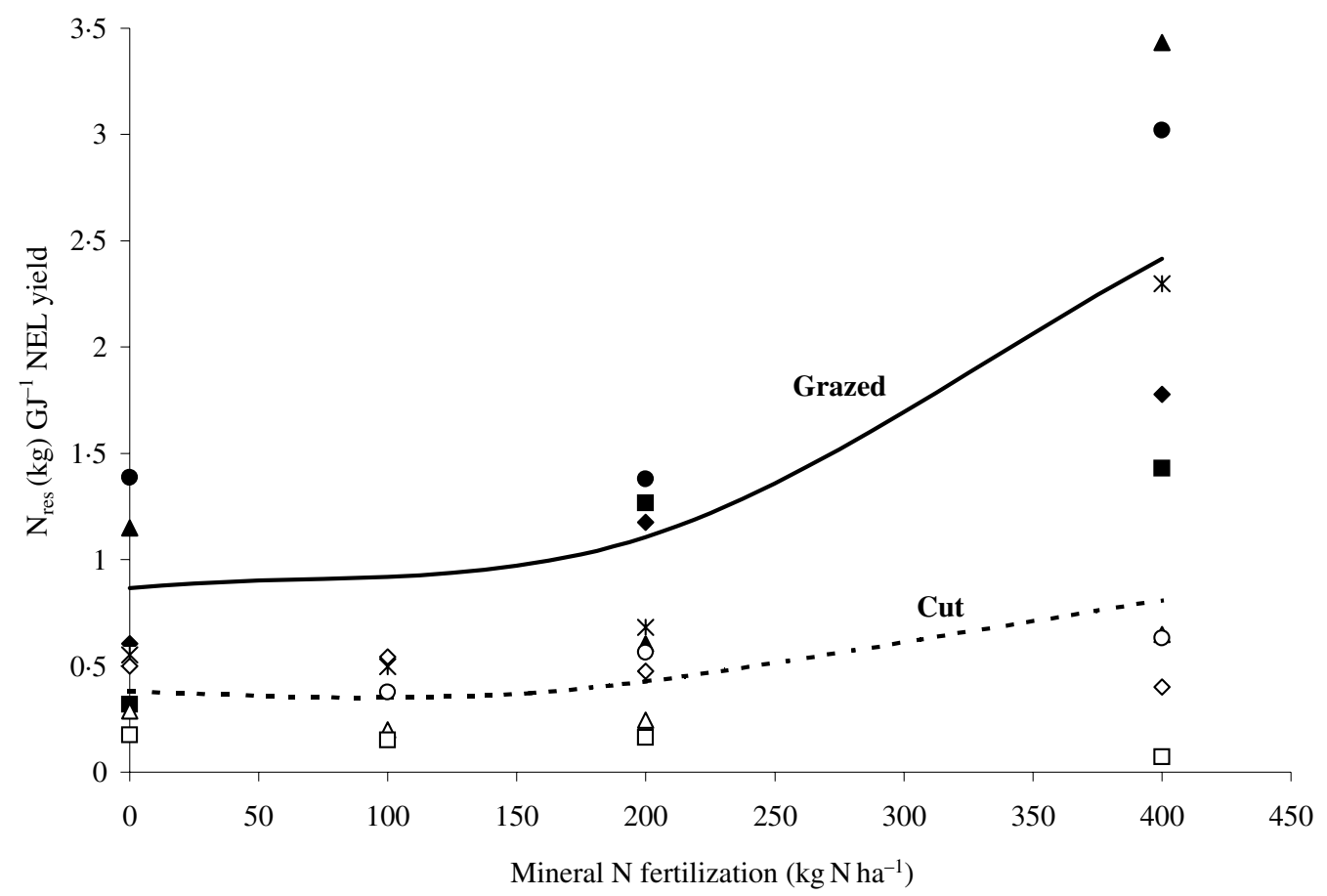

Figure 8 Relationship between inorganic $N$ application and the amount of residual soil nitrate- $N(0-90 \mathrm{~cm})$ per $G)$ NEL yield on the cut $(\mathbf{O})$ and grazed $(\bigcirc)$ grasslands.

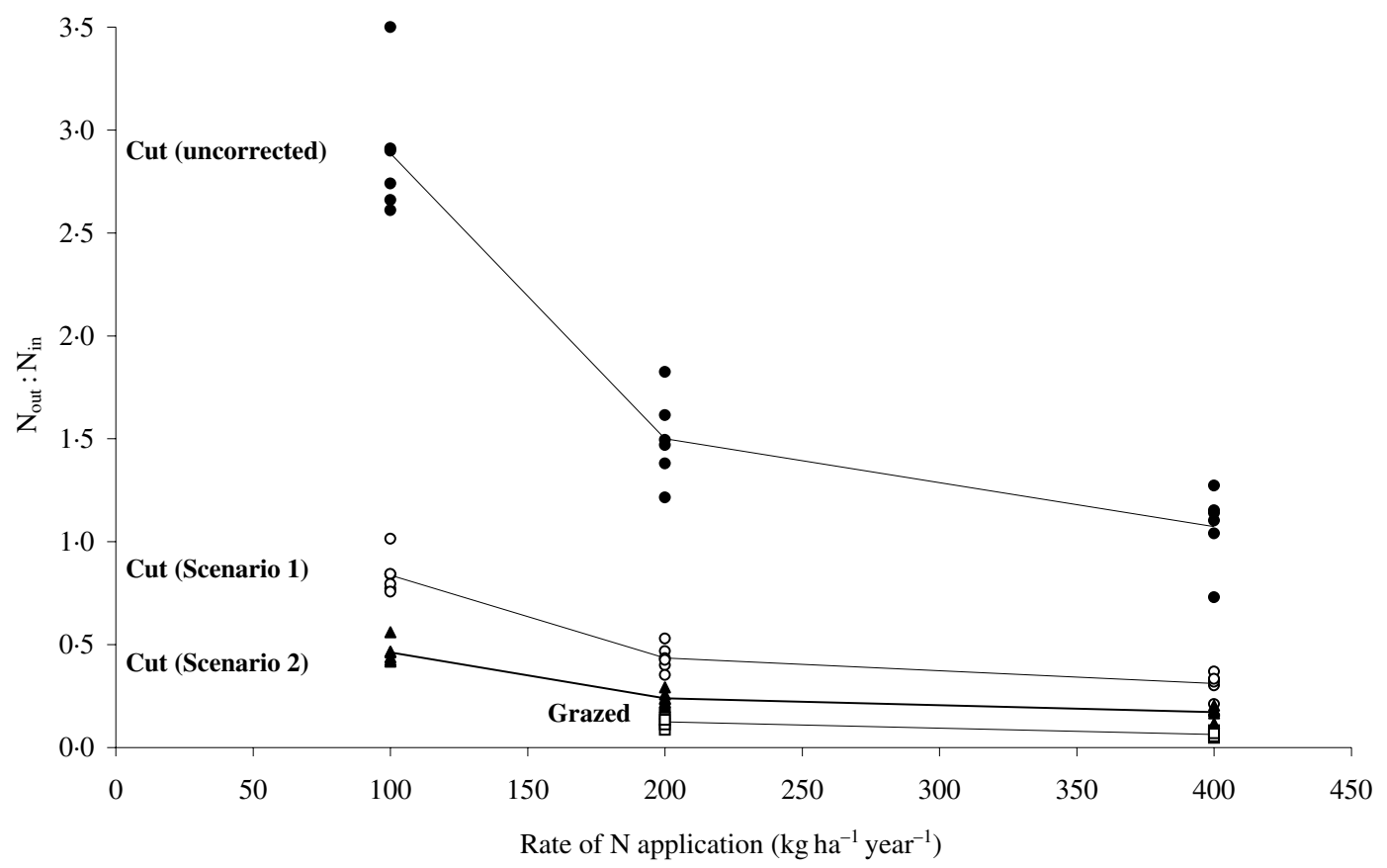

Figure 9 Ratio of $\mathrm{N}$ output to $\mathrm{N}$ input for the cut $(\mathbf{O})$ and the grazed $(\bigcirc)$ swards. For the cut grasslands, $\mathrm{N}$ output was corrected for losses occurring after herbage intake by livestock (scenario I: animal $\mathrm{N}$ use efficiency $=0 \cdot 20$; scenario 2: animal $\mathrm{N}$ use efficiency $=0 \cdot 10)$. 
(Goelema et al., 1996; Van Bruchem et al., 1996). The other $0 \cdot 80$ of $\mathrm{N}$ intake mainly ends up in manure. It was also assumed that 0.40 of the $\mathrm{N}$ in manure $\mathrm{N}$ will be used efficiently by the forage crop on which it is applied (Van Bruchem et al., 1996) and 0.60 will be lost by volatilization, denitrification and leaching. The harvested forage crop returns to the animal compartment and the same loop was followed another three times. By then, there is a net $\mathrm{N}$ output (in animal production) of $29 \mathrm{~kg} \mathrm{~N}$ per $100 \mathrm{~kg} \mathrm{~N}$ initially taken up from harvested herbage. In this respect, the corrected $\mathrm{N}$ output of the cut grassland is $0 \cdot 29 \mathrm{~N}_{\text {out }}$ for scenario 1 .

In the second scenario, focused on growing animals, it is assumed that only $0 \cdot 10$ of the amount of the herbage $\mathrm{N}$ taken up is retained in net animal production (Watson and Foy, 2001). Other assumptions and the method were the same as before. This resulted in a net $\mathrm{N}$ output (in animal production) of $16 \mathrm{~kg} \mathrm{~N}$ per $100 \mathrm{~kg} \mathrm{~N}$ initially taken up from harvested herbage. In this respect, the corrected $\mathrm{N}$ output for growing animals is $0 \cdot 16 \mathrm{~N}_{\text {out }}$.

Using these corrected $\mathrm{N}_{\text {out }}$ values, the global efficiency of the cut grassland system is lower with scenario 1 values of 0.35 and 0.25 at $\mathrm{N}$ rates of 200 and $400 \mathrm{~kg} \mathrm{ha}^{-1} \mathrm{yr}^{-1}$ respectively (Figure 9). For scenario 2 these were $0 \cdot 19$ and $0 \cdot 14$. These values are still higher than on grazed grassland $(0.12$ and 0.06 at $200 \mathrm{~N}$ and $400 \mathrm{~N}$ respectively) but the overall $\mathrm{N}$-use efficiency of both systems was remarkable (Figure 9 ).

\section{Conclusions}

On cut grassland, the economically optimal $\mathrm{N}$ fertilizer rate was at least $400 \mathrm{~kg} \mathrm{ha}^{-1} \mathrm{yr}^{-1}$. This $\mathrm{N}$ application resulted in amounts of residual soil nitrate $(0-90 \mathrm{~cm})$ below the present or possibly revised legal limits of 90 and $70 \mathrm{~kg}$ nitrate- $\mathrm{N} \mathrm{ha}^{-1}$ respectively. When cutting management aims at a substantial yield resulting from the white clover content in the sward, $\mathrm{N}$ fertilizer application rates should be limited to $100 \mathrm{~kg} \mathrm{ha}^{-1} \mathrm{yr}^{-1}$.

On grassland grazed by heifers, it was not economically justified to apply more than $200 \mathrm{~kg} \mathrm{~N} \mathrm{ha}^{-1} \mathrm{yr}^{-1}$. According to the present Flemish legal threshold on the amount of residual soil nitrate- $\mathrm{N}\left(90 \mathrm{~kg} \mathrm{ha}^{-1}, 0-90 \mathrm{~cm}\right)$, this $\mathrm{N}$ rate was also the maximum from an environmental point of view. If the limit were revised to e.g. $70 \mathrm{~kg} \mathrm{~N} \mathrm{ha}^{-1}$, then the environmental optimum $\mathrm{N}$ rate would be about $150 \mathrm{~kg} \mathrm{~N} \mathrm{ha}^{-1} \mathrm{yr}^{-1}$. Restricted to the grassland paddock scale, overall $\mathrm{N}$-use efficiency $\left(\mathrm{N}_{\text {out }}: \mathrm{N}_{\text {in }}\right)$ on cut plots was ten to twelve times higher than on grazed plots. However, the $\mathrm{N}_{\text {out }}: \mathrm{N}_{\text {in }}$ ratio was only two to four times higher on the cut plots when feeding the cut grass to livestock was included.

\section{Acknowledgments}

The cutting experiment was carried out at the National Centre for Grassland and Forage Research, 2nd section, and was financed by the Ministry of Agriculture, R \& D Department, Brussels. The grazing experiment was carried out by the Plant Production Department of Ghent University and was financed by the European Community within the framework of EC regulation 2078/92.

\section{References}

AlBERDA T. (1971) Stikstofbemesting van grasland en kwaliteit van het oppervlaktewater [Nitrogen fertilization of grassland and surface water quality]. Stikstof, 69, 377383 (in Dutch).

Andrieu J., Demarquilly C. and Sauvant D. (1988) Tables de la valeur nutritive des aliments [Tables of feeding value of feeds]. In: Jarrige R. (ed.) Alimentation des bovins, ovins et caprins, pp. 356-444. Paris: Institut de la Recherche Agronomique (in French).

Anonymous (1991) Council Directive of 12 December 1991 concerning the protection of waters against pollution caused by nitrates from agricultural sources (91/676/ EEC). Official Journal of the European Communities, L375, $1-8$.

Anonymous (1999) Jungviehweiden: $100 \mathrm{~kg} N$ pro ha reichen! [Grassland for heifers: will $100 \mathrm{~kg} \mathrm{~N}$ per ha do!]. Top Agrar, 3/99, 22-24 (in German).

ANONYmous (2000a) MINAS tabellenbrochure 2001 (MINAS brochure of tables). http://www.minlnv.nl/minas/bib/ brochure.

Anonymous (2000b) Kostprijsraming ruwvoeders 2000 [Cost price estimations of forages 2000]. Boer en Tuinder, 17 November 2000, 12-13 (in Dutch).

Anonymous (2001) Open ruimte in Vlaanderen [Open space in Flanders]. Jaarverslag 2000 van de Vlaamse Landmaatschappij. Brussels: Vlaamse Landmaatschappij (in Dutch).

Armitage E.R. and Templeman W.G. (1964) Response of grassland to nitrogenous fertilizer in the West of England. Journal of the British Grassland Society, 19, 291-297.

BAARS T. (2001) The conflict in organic grass/clover production: white clover versus animal manure. In: Isselstein J., Spatz G. and Hofmann M. (eds) Organic Grassland Farming. Proceedings of the International Occasional Symposium of the European Grassland Federation, Witzenhausen, Germany, pp. 241-243.

BAKER R.D. (1982) Estimating herbage intake from animal performance. In: Leaver J.D. (ed.) Herbage Intake Handbook, pp. 77-93. Hurley: The British Grassland Society.

Ball P. and Keeney D. (1981) Nitrogen losses from urineaffected areas of a New Zealand pasture under contrasting seasonal conditions. Proceedings of the 14th International Grassland Congress, Lexington, USA, pp. 342-344. 
Barraclough D., Hyden M.J. and Davies G.P. (1983) Fate of fertilizer nitrogen applied to grassland. I. Field leaching results. Journal of Soil Science, 34, 483-497.

Behaeghe T. (1983) Proefresultaten i.v.m. de stikstofbemesting en uitspoeling van mineralen [Experimental results on $\mathrm{N}$ fertilization and nutrient leaching]. Studiedag Koninklijke Vlaamse Ingenieursvereniging, Heverlee, Belgium, 24 November 1983, pp. 3.1-3.11.

BeHAeghe T. and Carlier L. (1973) Influence of nitrogen levels on quality and yield of herbage under mowing and grazing conditions. Proceedings of the 5th General Meeting of the European Grassland Federation, Uppsala, Sweden, pp. 52-66.

BenKe M., Kornher A. and Taube E. (1992) Nitrate leaching from cut and grazed swards influenced by nitrogen fertilization. Proceedings of the 14th General Meeting of the European Grassland Federation, Lahti, Finland, pp. 184188.

Berentsen P.B., Giesen G.J. and Renkema J.A. (2000) Introduction of seasonal and spatial specification to grass production and grassland use in a dairy farm model. Grass and Forage Science, 55, 125-137.

Boxem T. (1973) Stikstofbemesting en bruto-opbrengst van grasland [Nitrogen fertilization and gross yield of grassland]. Stikstof, 73, 536-545 (in Dutch).

Bransby D.I. and Maclaurin A.R. (2000) Designing animal production studies. In: 't Mannetje L. and Jones R.M. (eds) Field and Laboratory Methods for Grassland and Animal Production Research, pp. 327-352. Wallingford, UK: CAB International.

Brockman J.S. (1971) Potassium requirements of intensive grass as related to system of utilization. In: Potassium and Systems of Grassland Farming. First Colloquium of the Potassium Institute Ltd, Oxfordshire, UK, pp. 63-71.

Brockman J.S. and Wolton K.M. (1963) The use of nitrogen on grass/white clover swards. Journal of the British Grassland Society, 18, 7-13.

Brown C.S., Carpenter P.N. and Belyea P.R. (1969) Fertilization Responses of Hay Land Grasses in Maine, Bulletin 676. ME, USA: Maine Agricultural Experimental Station.

Brown L., Scholefield D., Jewkes E.C., Preedy N., Wadge K. and ButLer M. (2000) The effect of sulphur application on the efficiency of nitrogen use in two contrasting grassland soils. Journal of Agricultural Science, Cambridge, 135, 131-138.

Bussink D.W. (1992) Ammonia volatilization from grassland receiving nitrogen fertilizer and rotationally grazed by dairy cattle. Fertilizer Research, 33, 257-256.

Bussink D.W. (1994) Relationships between ammonia volatilization and nitrogen fertilizer application rate, intake and excretion of herbage nitrogen by cattle on grazed swards. Fertilizer Research, 38, 111-121.

C.V.B. (Centraal Veevoederbureau) (1992) Handleiding voederwaardeberekening ruwvoeders [Manual for Calculation of the Feeding Value of Forages]. Lelystad, The Netherlands: Centraal Veevoederbureau (in Dutch).

Carlier L., Janssen G., Konings V. and Tyvaert D. (1992) Mineralenbalans [Mineral budgets]. Landbouwtijdschrift, 45, 447-459 (in Dutch).
Coates D.B. and Penning P. (2000) Measuring animal performance. In: 't Mannetje L. and Jones R.M. (eds) Field and Laboratory Methods for Grassland and Animal Production Research, pp. 353-402. Wallingford, UK: CAB International.

Cottenie A. and Velghe G. (1973) Het gebruik van de specifieke nitraatelektrode voor de bepaling van nitraten in gronden en planten [The use of the nitrate specific electrode for determination of nitrates in soils and plants]. Mededelingen van de Faculteit van de Landbouwwetenschappen, Rijksuniversiteit Gent, $\mathbf{3 8}$, $560-568$.

CowLing D.W. (1961) The effect of white clover and nitrogen fertilizer on the production of a sward. I. Total annual production. Journal of the British Grassland Society, 16, 281-290.

Davies W. and Williams T.E. (1958) Fertilizers and grassland. Proceedings of the Fertilizer Society, London, 15, 136.

DE VRIES D. (1933) De rangorde-methode, een schattingsmethode voor plantkundig graslandonderzoek met volgorde-bepaling [The Ranking Method, An Estimation Method for Botanical Grassland Research with Determination of Ranking Order]. Verslagen van Landbouwkundige Onderzoekingen, 'S Gravenhage, the Netherlands, no. 39 A (in Dutch).

De VRies D. (1948) Method and survey of the characterization of Dutch grasslands. Vegetatio, 1, 51-57.

Decau M. and Le Corre L. (1994) A drained plot study of the impact of cutting and/or grazing management and $\mathrm{N}$ fertilization on nitrate leaching under grassland. Proceedings of the 15th General Meeting of the European Grassland Federation, Wageningen, The Netherlands, pp. 382-386.

De Clerq M. and Salette J. (1994) Reducing nitrate leaching by manipulating the cutting/grazing and $\mathrm{N}$ fertilization level regimes. Workshop Proceedings of the 15th general Meeting of the European Grassland Federation, Wageningen, The Netherlands, pp. 213-217.

Declerco P., Salomez J. and Hofman G. (2001) Environmental pressures and national environmental legislation with respect to nutrient management in Belgium. In: De Clercq P., Gertsis A.C., Hofman G., Jarvis S.C., Neeteson J.J. and Sinabell F. (eds) Nutrient Management Legislation in European Countries, pp. 56-77. Wageningen, The Netherlands: Wageningen Press.

DEENEN P.J. (1994) Nitrogen use efficiency in intensive grassland farming. Ph.D. thesis, The Netherlands: Wageningen University.

Deenen P. and Lantinga E. (1993) Herbage and animal production responses to fertilizer nitrogen in perennial ryegrass swards. I. Continuous grazing and cutting. Netherlands Journal of Agricultural Science, 41, 179-203.

Dowdell R.J. and Webster C.P. (1980) A lysimeter study using nitrogen-15 on the uptake of fertilizer nitrogen by perennial ryegrass swards and losses by leaching. Journal of Soil Science, 31, 65-75.

Dowdell R., Morrison J. and Hood A. (1980) The fate of fertilizer nitrogen applied to grassland: uptake by plants, immobilisation into soil organic matter and losses by leaching and denitrification. In: Proceedings of the 
International Symposium of the European Grassland Federation on the Role of Nitrogen in Intensive Grassland Production, Wageningen, The Netherlands, pp. 129-136.

Elgersma A., NASSiri M. and Schlepers H. (1998) Competition in perennial ryegrass-white clover mixtures under cutting. I. Dry matter yield, species composition and nitrogen fixation. Grass and Forage Science, 53, 353-366.

Elgersma A., Schlepers H. and NASSIRI M. (2000) Interactions between perennial ryegrass and white clover under contrasting nitrogen availability: productivity, seasonal patterns of species composition, nitrogen yield, $\mathrm{N} 2$ fixation, $\mathrm{N}$ transfer and $\mathrm{N}$ recovery. Plant and Soil, 221, 281-299.

Farrugia A., Decau M.L., Vertès F. and Delaby L. (1997) En prairie, la balance azotée à l'échelle de la parcelle [Nitrogen balance on the plot scale in grazed pastures]. Fourrages, 151, 281-296 (in French).

Flachowsky G. (1993) Bewertung der Futtermittel [Evaluation of feeds]. In: Jeroch H., Flachowsky G. and Weissbach F. (eds) Futtermittelkunde, pp. 33-73. Stuttgart: G. Fischer Verlag (in German).

Frame J. and Boyd A.G. (1986) Effect of cultivar and seed rate perennial ryegrass and strategic fertilizer nitrogen on the productivity of grass/white clover swards. Grass and Forage Science, 41, 359-366.

Frame J. and Boyd A.G. (1987) The effect of strategic use of fertilizer nitrogen in spring and/or autumn on the productivity of a perennial ryegrass/white clover sward. Grass and Forage Science, 42, 429-438.

Frame J. and Newbould P. (1986) Agronomy of white clover. Advances in Agronomy, 40, 1-88.

Frame J., Charlton J.F.L. and Laidlaw A.S. (1998) Temperate Forage Legumes. Wallingford, UK: CAB International.

Garrett M., Watson C., Jordan C., Steen R. and Smith R. (1992) The nitrogen economy of grazed grassland. Proceedings of the Fertilizer Society, 326, 1-32.

Garwood E., Salette J. and Lemaire G. (1980) The influence of water supply to grass on the response to fertilizer nitrogen and nitrogen recovery. Proceedings of the International Symposium of the European Grassland Federation on the Role of Nitrogen in Intensive Grassland Production, Wageningen, The Netherlands, pp. 59-65.

Goelema J.O., Van Bruchem J. and Tamminga S. (1996) Nitrogen efficiency of dairying in relation to dietary protein content and degradability. In: Groen A.F. and Van Bruchem J. (eds) Utilization of Local Feed Resources by Dairy Cattle. EAAP Publication No. 84, pp. 128-130. Wageningen, The Netherlands: Wageningen Press.

Hack-Ten Broeke M.J. (2000) Nitrate leaching from dairy farming on sandy soils. Ph.D. thesis, The Netherlands: Wageningen University.

Hofman G. (1983) Minerale stikstofevolutie in zandleemprofielen [Evolution of mineral nitrogen in sandy loam soils]. Ph.D. thesis, Belgium: Ghent University.

Holliday R. and Wilman D. (1965) The effect of fertilizer nitrogen and frequency of defoliation on yield of grassland herbage. Journal of the British Grassland Society, 20, 32-40.
Hopkins A. (2000) Herbage production. In: Hopkins A. (ed.) Grass, Its Production and Utilization, pp. 90-110. Oxford, UK: Blackwell Science.

Hopkins A., Murray P.J., Bowling P.J., Rook A.J. and Johnson J. (1995) Productivity and nitrogen uptake of ageing and newly sown swards of perennial ryegrass (Lolium perenne L.) at different sites and with different nitrogen fertilizer treatments. European Journal of Agronomy, 4, 65-75.

I.K.C. (1993) Handboek voor de rundveehouderij [Manual for cattle husbandry]. Publication no. 35. Lelystad, The Netherlands: Informatie - en Kenniscentrum Veehouderij.

JaCKSON M.V. and WiLliams T.E. (1979) Response of grass swards to fertilizer $\mathrm{N}$ under cutting or grazing. Journal of Agricultural Science, Cambridge, 92, 549-562.

JARVIS S. (1990) Ammonia volatilization from grazed grassland: effects of management on annual losses. In: Merckx R., Vereecken H. and Vlassak K. (eds) Fertilization and the Environment, pp. 297-304. Leuven: Leuven University Press.

JARVIS S. and BARRAClOUGH D. (1991) Variation in mineral nitrogen under grazed grassland swards. Plant and Soil,

138, 177-188.

JARvis S. and Cuttle S. (1987) Manipulating the fate of nitrogen in grazed swards. In: Hardcastle J.E.Y. (ed.) Science and Better Use of Grassland, pp. 20-21. London: Agriculture and Food Research Council.

Jarvis S., Hatch D. and Roberts D. (1989) The effects of grassland management on nitrogen losses from grazed swards through ammonia volatilization: the relationship to excretal $\mathrm{N}$ returns from cattle. Journal of Agricultural Science, Cambridge, 112, 205-216.

JoRDAN C. (1989) The effect of fertilizer type and application rate on denitrification losses from cut grassland in Northern Ireland. Fertilizer Research, 19, 45-55.

Kent M. and CoKer P. (1992). Vegetation Description and Analysis. Boca Raton, FL: CRC Press.

LAIDLAW A.S. (1980) The effects of nitrogen fertilizer applied in spring on swards of ryegrass sown with four cultivars of white clover. Grass and Forage Science, 35, 295-299.

LAIDLAW A.S. (1984) Quantifying the effect of nitrogen fertilizer applications in spring on white clover content in perennial ryegrass-white clover swards. Grass and Forage Science, 39, 317-321.

LANTINGA E. and Groot J. (1996) Optimization of grassland production and herbage feed quality in an ecological context. In: Uitlization of Local Feed Resources by Dairy Cattle. Proceedings of an International Symposium, Wageningen, The Netherlands. EAAP Publication No. 84, pp. 58-66.

Lantinga E., Keuning J., Groenwold J. and Deenen P. (1987) Distribution of excreted nitrogen by grazing cattle and its effects on sward quality, herbage production and utilization. In: Van Der Meer H.G., Unwin R.J., Van Dijk T.A. and Ennik G.C. (eds) Animal Manure on Grassland and Fodder Crops, pp. 103-177. Dordrecht: Martinus Nijhoff Publishers.

Lehmann J., Rosenberg E. and Briner H.-U. (2001) Modell für die Berechnung des Ertrages von Klee-GrasMischungen [A model for the calculation of yields of 
grass/clover mixtures]. Agrarforschung, 8, 364-369 (in German).

LiNeHAN P.A. and Lowe J. (1960) Yielding capacity and grass/clover ratio of herbage swards as influenced by fertilizer treatments. Proceedings of the 8th International Grassland Congress, Reading, England, pp. 133-137.

MACDUfF J., JARVIS S. and RoberTs D. (1990) Nitrate leaching under grazed grassland: measurements using ceramic cup soil solution samplers. In: Merckx R., Vereecken H. and Vlassak K. (eds) Fertilization and the Environment, pp. 297304. Leuven: Leuven University Press.

'T MANnetJe L. and Jarvis S. (1990) Nitrogen flows and losses in grasslands. Proceedings of the 13th General Meeting of the European Grassland Federation, Banska Bystricca, Czechoslovakia, Vol. 1, pp. 114-131.

MAyne C.S., Wright I.A. and Fisher G.E.J. (2000) Grassland management under grazing and animal response. In: Hopkins A. (ed.) Grass, Its Production and Utilization, 3rd edn, pp. 247-291. Oxford: Blackwell Science.

Morrison J. (1980) The influence of climate and soil on the yield of grass and its response to fertilizer nitrogen. In: Prins W.H. and Arnold G.H. (eds) The Role of Nitrogen in Intensive Grassland Production. Proceedings of an International Symposium of the European Grassland Federation, Haren, The Netherlands, pp. 51-57.

Morrison J., Jackson M.V. and Sparrow P.E. (1980) The response of perennial ryegrass to fertilizer nitrogen in relation to climate and soil: report of the joint ADAS/GRI grassland manuring trial - GM.20. Technical Report, no. 27. Hurley, UK: Grassland Research Institute.

Morrison J., Denehy K. and Chapman P.F. (1983) Possibilities for the strategic use of fertilizer $\mathrm{N}$ on white clover/grass swards. In: Corrall A.J. (ed.) Efficient Grassland Farming. British Grassland Society Occasional Symposium No. 14, pp. 227-231. Hurley, UK: British Grassland Society.

Neeteson J.J. and Wadman W.P. (1987) Assessment of economically optimum application rates of fertilizer $\mathrm{N}$ on the basis of response curves. Fertilizer Research, 12, 37-52.

Nevens F. and Reheul D. (1999) Voordroogkuil: vandaag maaien, morgen inkuilen met minimale verliezen [Silage of wilted grass: mowing today, ensiling tomorrow with minimal losses]. In: Gras, van veld tot voer, pp. 34-44. SintKatelijne-Waver, Belgium: Landbouwcentrum voor Voedergewassen vzw (in Flemish).

Nevens F. and Reheul D. (2003) Permanent grassland and 3-year leys alternating with 3-year arable land: 31 years of comparison. European Journal of Agronomy, 19, 77-90.

ORR S.J. and LAIDLAW A.S. (1978) The effects of nitrogen on grass and grass/clover swards under two cutting frequencies. Record of Agricultural Research, Department of Agriculture for Northern Ireland, 26, 41-53.

Prins W.H. (1983) Effect of a wide range of nitrogen applications on herbage nitrate content in long-term fertilizer trials on all-grass swards. Fertilizer Research, 4, 101-113.

REID D. (1970) The effects of a wide range of nitrogen application rates on the yields from a perennial ryegrass sward with and without white clover. Journal of Agricultural Science, Cambridge, 74, 227-240.

REID D. (1983) The combined use of fertilizer nitrogen and white clover as nitrogen sources for herbage growth. Journal of Agricultural Science, Cambridge, 100, 613-623.

Robson M.J., Parsons A.J. and Williams T.E. (1989) Herbage production: grasses and legumes. In: Holmes W. (ed.) Grass: Its Production and Utilization, pp. 7-88. Oxford, UK: Blackwell Scientific Publications.

Ryden J. (1983) Denitrification losses from a grassland soil in the field receiving different rates of nitrogen as ammonium nitrate. Journal of Soil Science, 34, 355-365.

Ryden J., Ball P. and Garwood E. (1984) Nitrate leaching from grassland. Nature, 311, 50-53.

SCHILS R. (1997) Effect of a spring application of nitrogen on the performance of perennial ryegrass-white clover swards at two sites in the Netherlands. Netherlands Journal of Agricultural Science, 45, 263-275.

SCHILS R. (2002) White clover utilisation on dairy farms in the Netherlands. Ph.D. thesis, The Netherlands: Wageningen University.

SCholefield D., Lockyer D., WhiteheAd D. and Tyson K. (1991) A model to predict transformations and losses of nitrogen in UK pastures grazed by beef cattle. Plant and Soil, 132, 165-177.

Scholefield D., Tyson K., Garwood E., Armstrong A., Hawkins J. and Stone A. (1993) Nitrate leaching from grazed grassland lysimeters: effects of fertilizer input, field drainage, age of sward and patterns of weather. Journal of Soil Science, 44, 601-613.

Sibma L. and Alberda Th. (1980) The effect of cutting frequency and nitrogen fertilizer rates on dry matter production, nitrogen uptake and herbage nitrate content. Netherlands Journal of Agricultural Science, 28, 243-251.

Simon J.-C., De Montard F., Le Corre L. and Pepin D. (1989) Rôle agronomique de la prairie dans la gestion du drainage des nitrates vers la nappe phréatique [Effect of pastures on the drainage of nitrates to groundwater]. Fourrages, 119, 227-241 (in French).

Van Bruchem J., Bosch M.W. and Oosting S.J. (1996). Nitrogen efficiency of grassland-based dairy farming new perspectives using an integrated approach. In: Groen A.F. and Van Bruchem J. (eds) Utilization of Local Feed Resources by Dairy Cattle, pp. 99-101. EAAP Publication No. 84. Wageningen, The Netherlands: Wageningen Press.

VAN DE Ven, G.W.J. (1990) De kaliumkringloop op grasland. Centrum voor Agrobiologisch Onderzoek, Wageningen, The Netherlands, Verslag nr 132 (in Dutch).

Van der Meer H.G. and Meeuwissen P.C. (1989) Emissie van stikstof uit landbouwgronden in relatie tot bemesting en bedrijfsvoering [Emission of nitrogen from agricultural land in relation to fertilization and farm management]. Landschap, 6, 19-32 (in Dutch).

Van der Putten A.H.J. and Vellinga TH.V. (1996) De invloed van graslandgebruik op de benutting van de toegediende stikstof [The influence of grassland use on $\mathrm{N}$ use efficiency]. In: Loonen J.W. and Bach-de Wit W.E. (eds) Stikstof in beeld, naar een nieuw bemestingsadvies op grasland, Ede, The Netherlands, pp. 36-59 (in Dutch). 
VAn Es A.J.H. (1978) Feed evaluation for ruminants. I. The systems in use from May 1977 onwards in The Netherlands. Livestock Production Science, 5, 331-345.

Van Orshoven J., OORTS K., Librecht I., Rombauts S. and FEyen J. (2002) Richtwaarde voor de residuele nitraatstikstof in de bodem: modelaanpak, resultaten en ruimtelijke differentiatie [Target value for residual nitrate- $\mathrm{N}$ in the soil: model approach, results and spatial differentiation]. In: Stikstofproblemathiek in de landbouw: evaluatie, maatregelen en consequenties [The nitrogen problem in agriculture: evaluation, measures and consequences], pp. 59-87. Antwerp, Belgium: Koninklijke Vlaamse Ingenieursvereniging, Technologisch Instituut (in Flemish).

VAN SteEnBergen T. (1977) Invloed van grondsoort en jaar op het effect van stikstofbemesting op de graslandopbrengst. Stikstof, 85, 9-15 (in Flemish).

Vermoesen A. (1999) Aspects of nitrogen losses from grassland. Ph.D. thesis, Belgium: Ghent University.

Vertès F., Simon J.-C. and Le Corre L. (1994) Nitrate leaching under pastures: study of the soil-plant system in a lysimeter experiment. Proceedings of the 15th General meeting of the European Grassland Federation on Grassland and Society, Wageningen, The Netherlands, pp. 466-470.

VlaAmSE Regering (2000) Decreet van 23 januari 1991 inzake de bescherming van het leefmilieu tegen de verontreiniging door meststoffen [Decree of 23 January 1991 concerning the protection of the environment against pollution by fertilizers]. Belgisch Staatsblad, 3 March 2000 (in Flemish and in French).

WATSON C.J. and Foy R.H. (2001) Environmental impacts of nitrogen and phosphorus cycling in grassland systems. Outlook on Agriculture, 30, 117-127.

Watson C., Joran C. and Steen R. (1992) Annual N balances for grazed grassland. In: François E., Pithan K. and Bartiaux-Thill N. (eds) Nitrogen Cycling and Leaching in Cool and Wet Regions of Europe. COST 814 Workshop Proceedings, Gembloux, Belgium, pp. 35-37.
Weissbach F. and ERnst P. (1994) Nutrient budgets and farm management to reduce nutrient emissions. In: Grassland and Society. Proceedings of the 15th General Meeting of the European Grassland Federation, Wageningen, The Netherlands, pp. 343-360.

Whalley R.D.B. and HARDY M.B. (2000) Measuring botanical composition of grasslands. In: 't Mannetje L. and Jones R.M. (eds) Field and Laboratory Methods for Grassland and Animal Production Research, pp. 67-102. Wallingford, UK: CABI Publishing.

WhiteHEAD D. (1995) Grassland Nitrogen. Wallingford, UK: CAB International.

Wieringa G., Van der Meer H. and Geurink J. (1980) Production and utilization of energy and protein in grass in relation to nitrogen rate, green crop fractionation and dairy feeding systems. Proceedings of the International Symposium of the European Grassland Federation, Wageningen, The Netherlands, pp. 103-126.

Willems W.J., Vellinga T.V., Oenema O., Schroder J.J., VAN Der Meer H.G., Fraters B. and Aarts H.F.M. (2000) Onderbouwing van het Nederlandse derogatieverzoek in het kader van de Europese nitraatrichtlijn [The basis of the Dutch derogation request in the frame of the European nitrates directive]. Rijksinstituut voor Volksgezondheid en Milieu, Bilthove, the Netherlands, Rapport 718201002 (in Dutch).

Williams, T.E. (1980) Herbage Production. In: Holmes W. (ed.) Grass, Its Production and Utilization, pp. 6-69. Oxford, UK: Blackwell Scientific Publications.

Wilman D. and Asiegbu J.E. (1982) The effects of clover variety, cutting interval and nitrogen application on herbage yields, proportions and heights in perennial ryegrass-white clover swards. Grass and Forage Science, 37, 1-13.

Woolfolk P.G. (1962). Measuring yield by animal performance. In: Pasture and Range Research Techniques, pp. 73-75. New York: Comstock Publishing Associates. 